\title{
ANALISIS FILOSOFIS PEMERINTAHAN DAERAH DALAM PERGANTIAN (PERUBAHAN) KAIDAH HUKUM DASAR NEGARA
}

\author{
Agussalim Andi Gadjong ${ }^{1}$
}

\begin{abstract}
Local governments in Indonesia have a philosophical justification for the ideals and ideas of nationhood that was initiated by "The Founding Father" in the formulation and preparation of the constitutional debate in the founding of the Republic of Indonesia. Norms of the Constitution of 1945 NRI textually in the rules of Article 18. Article 18A and Article 18B law mandates figure in the implementation of local government as a whole in the concept of form and arrangement of the "Unity and the Republic. On the other hand, tends to the unitary conception of centralization, but in the context of the implementation of government in promoting the realization of Homeland remain decentralized governance in the region that followed the process and mechanism of the delegation of authority to provide local flexibility to be creative with the resources of human and natural resources in advancing the development in the region. However, in the process of delegation of authority in the delivery mechanism and delegation of authority to local governments through the application of the principle of decentralization, deconcentration and assistance task, leaving no aspect of unity in kerangkan unitary state. Due to the nature of the strengthening of autonomy does not mean loose and the widest without supervision and coordination with the central government.
\end{abstract}

Keywords:UUD 1945, decentralizatio, autonomy

\begin{abstract}
Abstrak
Pemerintahan Daerah di Indonesia mendapatkan justifikasi filosofis dalam cita dan idea bernegara yang digagas oleh "The Founding Father" dalam perdebatan perumusan dan penyusunan konstitusi dalam pendirian Negara Kesatuan Republik Indonesia. Norma UUD NRI Tahun 1945 secara tekstual dalam kaidah Pasal 18, Pasal 18A dan Pasal 18B mengamanatkan figur hukum dalam pelaksanaan pemerintahan daerah sebagai satu kesatuan dalam konsep bentuk dan susunan negara "Kesatuan dan Republik. Sementara disisi lainnya, konsepsi negara kesatuan cenderung terjadinya sentralisasi, tetapi dalam konteks pelaksanaan pemerintahan di NKRI tetap mengedepankan perwujudan desentralisasi pemerintahan di daerah yang diikuti proses dan mekanisme terjadinya
\end{abstract}

1 Penulis adalah Dosen Fakultas Hukum dan PPS UMI Makassar. Alamat Kontak: gadjong@gmail.com 
pendelegasian kewenangan dalam memberikan keleluasaan daerah untuk berkreasi dengan sumber daya manusia dan sumber daya alam dalam memajukan pembangunan di daerahnya. Namun, dalam proses pendelegasian kewenangan dalam mekanisme penyerahan dan pelimpahan kewenangan kepada pemerintah daerah melalui penerapan asas desentralisasi, dekonsentrasi dan tugas pembantuan, tidak meninggalkan aspek kesatuan dalam kerangkan negara kesatuan. Karena hakekat penguatan otonomi tidak berarti lepas dan seluas-luasnya tanpa pengawasan dan koordinasi dengan pemerintah pusat.

Kata kunci:UUD 1945, desentralisasi, otonomi

\section{Pendahuluan}

Aktualisasi penyelenggaraan negara dan pemerintahan dalam sejarah perjalanan ketatanegaraan Negara Kesatuan Republik Indonesia (NKRI), tidak terlepas dari dinamika dalam proses perumusan dasar-dasar pendirian negara pada sidang-sidang BPUPKI dan PPKI. Perdebatan dalam perumusan bentuk dan susunan negara, terfomat dalam dikotomi "Kesatuan" atau "Federal" dan antara "Republik" atau "Kerajaan", yang pada akhirnya lahir keputusan final untuk mendirikan negara dalam bentuk "republik" dengan susunan "kesatuan". Susunan kesatuan, memberikan wahana implementasi keragaman dalam satu ikatan negara, sementara bentuk republik, memberikan ruang implementasi konsep demokrasi dan/atau penguatan kedaulatan rakyat sampai pemerintahan di tingkat daerah.

The Foundhing Fathers NKRI, merumuskan dasar pendirian negara melalui pendekatan populistik, yang ditandai dengan pengadopsian ide-ide welfare state, dan pendekatan nasionalistik tercermin dalam pluralistik kebangsaan yang dibingkai dalam format "kesatuan-republik". Bentuk republik dan susunan kesatuan dirumuskan dalam pikiran moralis dan integralistik dalam satu kesatuan dan persatuan, yang di satu sisi mengedepankan aspek penegakan keadilan dan kepentingan negara yang bersifat universalistik, dan pada sisi lainnya aspek kepentingan individu partikularistik disingkirkan. Konstruksi pemikiran demikian

${ }^{2}$ RM. A. B. Kusuma, "Lahirnya Undang-Undang Dasar 1945", (Jakarta, Pusat Studi HTN FH-UI, 2004), hal. 153. Perdebatan tentang bentuk negara diawali pada sidang BPUPKI dalam masa sidang kedua antara tanggal 10 - 17 Juli 1945, khususnya pada tanggal 10 Juli 1945 yang mengagendakan pembicaraan tentang Bentuk Negara, yang dipimpin lansung oleh Dr. Radjiman dan R. P. Soeroso. Hasil sidang menunjukkan bahwa dari 64 stem (suara) yang masuk, 55 stem memilih republik, 6 stem memilih kerajaan, dan 2 stem memilih lain-lain serta 1 stem blangko. Lihat M. Yamin, Naskah Persiapan UUD 1945, (Jakarta, Prapanca, 1959), hal. 410. 
signifikan antara ide negara integralistik dengan slogan nasionalisme, seperti persatuan dan kesatuan yang terbingkai dalam Negara Kesatuan Republik Indonesia.

Format susunan negara kesatuan memberikan justifikasi kehadiran gagasan desentralisasi, yang bermakna terjadinya pemencaran (pembagian) kekuasaan atau "areal division of power" melalui mekanisme pendelegasian "attributive, delegative, mandaat", dari pemerintah pusat kepada pemerintah daerah. Mekanisme ini bermuara pada konsep "scope of power" dalam wujud sejauhmana luas atau lingkup kekuasaan (obyek, jenis, besaran) yang didelegasikan, dan konsep "domain of power" dalam wujud sejauhmana jangkauan (subyek, organ, jabatan) kekuasaan yang didelegasikan. ${ }^{3}$

Kewenangan pemerintahan daerah yang didelegasikan, bisa meliputi kewenangan zelfwetgeving dan zelfbestuur, yang mengakomodir kepentingan rakyat dalam penyelenggaraan pemerintahan secara demokratis. Namun, hakekat suatu negara kesatuan, pendelegasian kewenangan tidak bermakna lepas dari campur tangan dan kontrol pemerintah pusat, karena legal standing pemerintah daerah dalam hal ini bersifat "sub-ordinate" terhadap pemerintah pusat. ${ }^{4}$ Daerah selalu dituntut membangun hubungan yang harmonis dengan pusat, dan apabila bertindak di luar kontrol pusat maka dapat mengancam keutuhan "nation-state". Namun, hal tersebut bisa menjadi "pengingkaran" gagasan dasar pendirian NKRI dalam konsep "kesatuan dengan penguatan desentralisasi". Disisi lainnya, akan "mengeliminir" konsepsi pemerintahan daerah yang desentralistik, baik dalam susunan negara kesatuan maupun negara federal (local government also was the cornerstone of the governmental system $)^{5}$

Falsafah negara kesatuan dalam implementasinya, mengacu pada beberapa kecenderungan: Pertama, sifatnya sentralistik (concentrated-centralization), didasarkan pada pemikiran bahwa gerak kemajuan pembangunan nasional hanya

${ }^{3}$ Agussalim Andi Gadjong, "Pemerintahan Daerah, Kajian Politik dan Hukum", (Jakarta, Ghalia Indonesia, 2007), hal. 27. Lihat Laica Marzuki, Hukum dan Pembangunan Daerah Otonom, Kertas Kerja, PSKMP-LPPM UNHAS, 18 Nopember 1999, Makassar, hal. 1.

${ }^{4}$ Hans Kelsen, "General Theory of Law and State", (New York, Russell \& Russell, 1974), hal. 283-284. Lihat Jimly Asshiddiqie, "Gagasan Kedaulatan Rakyat dalam Konstitusi dan Pelaksanaannya di Indonesia”, (Jakarta, Ichtiar Baru Van Hoeve, 1994), hal. 25. Lihat Miriam Budiardjo, "Dasar-Dasar Ilmu Politik", (Jakarta, Gramedia, 1980), hal. 63-73 dan 104-105.

${ }^{5}$ James M. Banovets, "Managing Local Government, Cases in Decision Making, Municipal Management, International City Management Association”, $2^{\text {nd }}$, (Washintong: Printed, 1994), hal. 10. 
akan terjadi jika pemerintah pusat memegang kendali penuh dan segala sesuatunya diatur secara terpusat. Kedua, sifatnya desentralistik (disperse-local otonomy), memberikan jalan pemberdayaan segala potensi dan daya kreasi daerah. Ketiga, negara kesatuan memegang prinsip bahwa pemegang kekuasaan tertinggi ialah central government, yang tidak diganggu oleh adanya suatu pelimpahan atau penyerahan kewenangan kepada local government. ${ }^{6}$ Keempat, Kewenangan pemerintahan daerah mengacu asas pembagian kekuasaan yang tidak meninggalkan suatu kesatuan (eenheid) pemegang kekuasaan tertinggi, yaitu tetap di tangan pemerintah pusat.

Negara Republik Indonesia sebagai negara kesatuan, melandasi pelaksanaan pemerintahan di daerah pada asas desentralisasi atau staatskundige decentralisatie ${ }^{7}$ (desentralisasi ketatanegaraan) yang melahirkan makna otonomi, dengan substansi penyerahan kewenangan yang sifatnya untuk mengatur dan mengurus rumah tangga daerah. Konsep ini meletakkan kedudukan pemerintahan daerah dalam posisi sebagai subyek "institusi/lembaga otonom". Di samping itu, dikenal juga asas dekonsentrasi dengan substansi pelimpahan kewenangan dan asas medebewind dengan substansi penugasan dari pemerintah pusat, yang sifatnya untuk mengurus kewenangan pusat yang ada di daerah. Pada konsep ini daerah bukan sebagai "institusi/lembaga otonom", tetapi hanya berfungsi sebagai penyalur atau "wakil" pemerintah pusat di daerah.

\section{Penyusunan Dan Perumusan Kaidah Hukum Dasar Negara}

NKRI yang diproklamasikan pada Tanggal 17 Agustus 1945, sejak awal sudah digagas untuk mendirikan suatu negara yang menganut paham "unitaris" yang mengacu pada sendi "desentralisasi". Gagasan ini secara tersirat termaktub dalam

${ }^{6}$ C. F. Strong, "Modern Political Constitution", (London, Sidswick \& Jaclison Limited, 1960), hal. 80 \& 100.. Lihat Smith, B.C., "Decentralization: The Territorial Dimension of The State", (London, Asia Publishing House, 1985). Lihat K. C. Wheare, "Modern Constitutions", (London, Oxford University Press, 1966), hal. 14.

7 Laica Marzuki, "Berjalan-Jalan di Ranah Hukum", Buku Kesatu, (Jakarta, Sekjen \& Kepaniteraan MK-RI, 2006), hal. 151. Desentralisasi memang merupakan staatskundige decentralisatie bukan ambtelijke decentralisatie, seperti halnya dengan dekonsentrasi. Lihat R.Tresna, "Bertamasya Ke-Taman Ketatanegaraan", (Bandung, Dibya, tanpa tahun), hal. 31. 
penegasan kaidah Pasal 18 UUD 1945, ${ }^{8}$ yang sebelum disahkan oleh Panitia Perancang UUD sebagai Panitia Kerja BPUPKI menempatkan ketentuan mengenai pemerintahan daerah dalam Pasal 17 Rancangan UUD dengan penegasan kaidah: "pembagian daerah besar dan kecil, bentuk dan susunan pemerintahan di daerah, dasar permusyawaratan daripada sistem pemerintahan negara, dan hak asal-usul daerah yang bersifat istimewa". Kaidah pasal ini, tidak terlepas dari paham yang didasarkan pada aspek hukum, kedaulatan, keadilan dan HAM.9?

Gagasan desentralisasi menjadi perdebatan, sejak Hatta ${ }^{10}$ menggulirkan dalam rapat-rapat BPUPKI dan menjadi lebih konkret dalam forum PPKI, ketika Amir dan Ratulangi yang akhirnya diamini oleh Supomo dengan mengutarakan bahwa pengaturan lebih lanjut mengenai desentralisasi akan diatur dalam suatu UU. Perdebatan diawali oleh Dr. Amir Syarifuddin dengan menekankan pentingnya desentralisasi dan penataan susunan pemerintahan daerah di luar pulau Jawa. Sementara Ratulangi menekankan pemberian hak seluas-luasnya kepada daerah, tetapi dalam bingkai NKRI, sedangkan Supomo menekankan penyerahan urusan rumah tangga kepada daerah melalui mekanisme perundang-undangan. ${ }^{11}$

${ }^{8}$ Lawrence S. Finkelstein, The Indonesiaan Federal Problem, Facific Affair, XXI/3, September 1951, hal. 284.

${ }^{9}$ RM. A. B. Kusuma, Op. Cit., hal. 240. Hal ini dapat dilihat dari RUUD (terdiri dari 42 pasal termasuk aturan peralihan dan aturan tambahan) yang dibahas dalam rapat besar tanggal 13 Juni 2605 oleh Panitia Perancang UUD, yang di ketuai oleh Ir. Soekarno, tetapi dalam rapat besar tanggal 14 dan 15 Juli 1945 terjadi perubahan dalam RUUD (terdiri dari 35 pasal, 6 pasal aturan peralihan ditambah aturan tambahan), mengenai materi pemerintahan daerah termaktub dalam Pasal 17. Dalam RUUD ketiga yang diajukan pada Rapat Besar Tanggal 16 Juli 1945 materi pemerintahan daerah berubah dan diatur dalam Bab VI Pasal 18.

${ }^{10}$ Mohammad Hatta, "Kedaulatan Rakyat", (Surabaya: Usaha Nasional, 1967), hal. 13-14. Hatta, menafsirkan kata "dengan memandang dan mengingati dasar permusyawaratan dalam sistem pemerintahan negara, dan hak-hak asal-usul dalam daerah-daerah yang bersifat istimewa yang tercantum dalam UUD, menyatakan bahwa hak melakukan pemerintahan sendiri bagi segenap bagian rakyat menjadi sendi kerakyatan Indonesia".

${ }^{11}$ Ratulangi mengajukan pendapat "Bahwa saya tidak akan mengucapkan desentralisasi dan dekonsentrasi, tetapi pandangan supaya daerah di beberapa pulau besar diberi hak seluas-luasnya untuk mengurus keperluannya menurut pikirannya, kehendaknya, tentu dengan memakai pikiran persetujuan bahwa daerah-daerah itu adalah daerah daripada Indonesia". Sementara Supomo menyatakan: bahwa kalau membentuk UU tentang pemerintahan daerah pada dasarnya urusan rumah tangga harus diserahkan kepada pemerintah daerah, walaupun harus ada beberapa pengecualian. 
Pandangan ketiga orang (Amir, Ratulangi, Soepomo) peserta rapat PPKI, yang mengangkat kembali konsep pemerintahan daerah, didasari oleh pertimbangan: Pertama, ketentuan kaidah Pasal 17 dalam Rancangan UUD yang kemudian menjelma menjadi Pasal 18, tidak atau belum memberikan gambaran yang jelas dan tegas mengenai bentuk dan isi pemerintahan daerah, meskipun sudah ada anak kalimat "dengan memandang dan mengingat ( $i$ ) dasar permusyawaratan dalam (daripada) sistem pemerintahan negara, dan hak-hak asal-usul dalam daerahdaerah yang bersifat istimewa". Kedua, bertujuan untuk memperoleh jaminan mengenai bentuk dan isi pemerintahan tingkat daerah. ${ }^{12}$

Setelah kaidah Pasal 18 disahkan dalam UUD 1945, dapat dilihat prinsip yang terkandung di dalamnya, antara lain: (1) Kata wilayah NKRI akan dibagi dalam satuan-satuan pemerintahan yang tersusun dalam daerah besar dan kecil, mengandung makna penerapan prinsip desentralisasi teritorial. (2) Kata perintah kepada pembentuk UU (Presiden dan DPR) untuk mengatur desentralisasi teritorial dalam suatu UU organik, mengandung makna bahwa keberadaan daerah-daerah otonom harus dilembagakan secara formal dalam suatu aturan hukum, sebagai landasan pelaksanaan pemerintahan di daerah otonom. (3) Kata Perintah kepada pembentuk UU dalam menyusun UU tentang desentralisasi teritorial kembali dipertegas lagi dalam kata "memandang dan mengingati" dasar permusyawaratan dalam sistem pemerintahan serta hak asal-usul daerah yang bersifat istimewa.

Hak melaksanakan pemerintahan sendiri untuk mengatur dan mengurus rumah tangga mendapatkan landasan yang kuat dalam konstitusi, yang diperkuat dengan dasar persekutuan hukum teritorial atau dikenal pada Hindia Belanda sebagai watershappen yang termasuk dalam sendi desentralisasi fungsional. Dasar permusyawaratan berkaitan dengan pelaksanaan paham demokrasi secara menyeluruh, baik pemerintahan di tingkat pusat maupun pemerintahan di tingkat daerah, sebagai pengejawantahan perwujudan sendi kedaulatan rakyat yang bersinergis dalam sendi desentralisasi, di mana penjabaran desentralisasi ini

12 Pembicaraan Amir dan Ratulangi dan dipertegas oleh Supomo: (1) bahwa maksud pembagian daerah besar dan kecil tidak lain dari pembagian ke dalam daerah-daerah otonom; (2) bahwa isi otonomi adalah seluas-luasnya "asal saja dilakukan dengan permusyawaratan dan tidak membuat peraturan sendiri yang menentang dasar pemerintahan pusat". Pidato Supomo di hadapan BPUPKI tanggal 31 Maret 1945 menyatakan "dalam negara Indonesia yang berdasar pengertian negara integralistik itu, segala golongan rakyat, segala daerah yang mempunyai keistimewaan sendiri akan mempunyai tempat dan kedudukan sendiri, sebagai bagian organik dari negara seluruhnya. Soal pemerintahan apakah yang akan diurus oleh pemerintah pusat dan soal apakah yang akan diserahkan kepada pemerintah daerah, baik daerah besar maupun daerah kecil, semuanya tergantung daripada doelmatigheid, berhubungan dengan waktunya, tempatnya dan juga soalnya". 
memberikan wujud kewenangan daerah dalam mengurus dan mengatur pemerintahan di daerah. Paham kerakyatan ${ }^{13}$ secara langsung mengikutsertakan rakyat melalui wadah penguatan sendi desentralisasi, yang diwujudkan dalam penyerahan atau pelimpahan kewenangan untuk mengatur dan mengurus rumah tangga daerah.

Di samping itu, paham negara hukum tidak bisa diabaikan, karena mempunyai kedudukan yang sangat penting dalam membangun pondasi dasar pelaksanaan pemerintahan. Hukum dijadikan dasar dalam mengatur dan membatasi kekuasaan negara dan dibuat atas dasar kekuasaan dan kedaulatan rakyat. Perpaduan kedua paham ini akhirnya dibingkai dalam sebutan "negara hukum demokratis" (democratische rechtstaat) sebagai pengejawantahan pelaksanaan kedaulatan rakyat yang diberikan landasan hukum atau hukum yang diformulasi dalam formalistik kedaulatan rakyat dalam segi penyusunan dan pembuatannya. Dengan kata lain, bahwa kedaulatan rakyat merupakan unsur material negara hukum. Perpaduan konsep negara hukum dan kedaulatan rakyat dikaitkan dengan desentralisasi di samping dekonsentrasi, maka akan ditemukan adanya pemencaran kekuasaan (spreiding van machten).

\section{Pergantian (Perubahan) Kaidah Hukum Dasar Negara}

Pemberlakuan UUD RI Tahun 1945 (Periode I - Proklamasi NKRI) sebagai konstitusi negara ${ }^{14}$, khususnya kaidah yang termaktub dalam Pasal 18, secara tersirat dapat ditafsirkan sebagai pengaturan pemerintahan di daerah dengan mengedepankan aspek desentralisasi. Namun, tidak menegaskan secara tersurat mengenai bentuk dan susunan pemerintahan di daerah, demikian pula sifat otonominya. Ketidakjelasan ini memungkinkan Soepomo memberikan penafsiran dalam Penjelasan UUD 1945, yang

${ }^{13}$ Moh. Hatta, "Demokrasi Asli Indonesia dan Kedaulatan Rakyat", (Jakarta, Bulan Bintang, 1976), hal. 124. Prinsip kerakyatan yang menjiwai penyusunan UUD 1945, diadopsi dari sendi pemerintahan desa dengan pandangan "bahwa dasar-dasar demokrasi yang terdapat dalam pergaulan asli di Indonesia kita pakai sebagai sendi politik kita. Akan tetapi, kita insaf akan pertukaran zaman, bahwa dasar-dasar yang ada dahulu itu tidak mencukupi sekarang untuk menyusun Indonesia merdeka yang berdasar demokrasi".

${ }^{14}$ Kedudukan UUD Tahun 1945 sebagai konstitusi negara diputuskan dan disahkan oleh Panitia Persiapan Kemerdekaan Indonesia (PPKI) dalam sidangnya tanggal 18 Bulan 8 Tahun 2605 (1945) di Jakarta. Penjelasan Umum butir I menegaskan bahwa UUD suatu negara ialah hanya sebagian dari hukumnya dasar negara itu. UUD ialah hukum yang tertulis, sedang di sampingnya UUD itu berlaku juga hukum dasar yang tidak tertulis, yaitu aturan-aturan dasar yang timbul dan terpelihara dalam praktik penyelenggaraan negara, meskipun tidak tertulis. 
memberi ruang susunan administratif di samping yang bersifat otonom. ${ }^{15}$ Disamping itu, membuat pembentuk UU untuk "bisa" berkreasi dalam menerbitkan aturan yang berbeda satu sama lain mengenai susunan dalam pelaksanaan pemerintahan daerah.

Penjabaran kaidah Pasal 18 UUD 1945, kemudian ditindaklanjuti dengan keluarnya Penetapan PPKI Tanggal 19 Agustus $1945^{16}$ mengenai pembagian wilayah (daerah) pemerintahan, tetapi belum dalam rangka melaksanakan amanat desentralisasi pemerintahan di daerah. Pembentukan daerah semata-mata bertujuan untuk : Pertama, mengisi kekosongan pemerintahan yang ditinggalkan pemerintahan pendudukan Jepang. Kedua, untuk sesegera mungkin melengkapi susunan pemerintahan RI, sehingga kehadiran RI yang merdeka dan berdaulat menjadi nampak nyata sampai ke daerah. Kenyataan di lapangan, susunan pemerintahan tingkat daerah tidak hanya terbatas pada provinsi, karesidenan, kota, swapraja (kooti), tetapi susunan kawedanan, kecamatan, dan desa tetap ada dan berjalan terus.

${ }^{15}$ BPUPKI maupun PPKI yang merancang, menyusun, mensyahkan dan menetapkan UUD tidak pernah membuat atau memutuskan membuat memori penjelasan sebagai penjelasan resmi (penjelasan otentik) UUD. Penjelasan UUD 1945 pertama kali muncul dalam Berita Republik II 1946 Tahun II No. 7. Jadi, penjelasan UUD 1945 ada setelah UUD 1945 dijalankan bahkan telah mengalami perubahan akibat Maklumat Pemerintah Tanggal 3 Nopember 1945. Berita Republik menurut Peraturan Pemerintah Nomor 1 Tahun 1945 adalah lembaran resmi tempat mengumumkan UU dan Peraturan Presiden. Pemuatan dalam Berita Republik, sama sekali tidak menyebabkan penjelasan UUD 1945 menjadi mempunyai sifat dan kedudukan hukum mengikat. Alasan tidak mengikatnya penjelasan UUD 1945 tersebut, antara lain : Pertama, kembali kepada fungsi dasar memori penjelasan yang tidak mempunyai sifat dan kedudukan hukum tertentu, melainkan sekedar untuk lebih memahami arti yang termuat dalam batang tubuh peraturan; Kedua, penjelasan yang dimuat dalam Berita Republik tidak dibuat oleh badan yang menyusun dan menetapkan UUD (BPUPKI dan PPKI) dan pemuatan penjelasan dalam Berita Republik bertentangan dengan bunyi PP Nomor 1 Tahun 1945 yang dengan tegas menyatakan bahwa yang dimuat dalam Berita Republik adalah UU dan peraturan presiden; Ketiga, pemuatan penjelasan dalam Berita Republik merupakan suatu kekeliruan atau kesalahan dalam melakukan suatu perbuatan hukum, yang secara lansung tidak menciptakan hukum.

${ }^{16}$ Penetapan PPKI dalam Rapatnya tanggal 19 Agustus 1945 di Jakarta, yang termuat dalam Berita Republik Indonesia Tahun II No. 7, halaman 48, kolom 2, menetapkan pembagian wilayah pemerintah RI di daerah dalam susunan teritorial: provinsi, karesidenan, kooti (swapraja) dan kota (gemeente), yaitu : (1) untuk sementara daerah RI dibagi menjadi delapan provinsi: Jawa Barat, Jawa Tengah, Jawa Timur, Sumatra, Kalimantan (Borneo), Sulawesi, Maluku, dan Sunda Kecil. Masingmasing Provinsi di Kepalai seorang Gubernur dan dibantu KNID (provinsi); (2) provinsi dibagi menjadi karesidenan-karesidenan yang dikepalai oleh seorang residen dan dibantu KNID (Karesidenan); (3) kedudukan kooti dan kota diteruskan seperti sekarang (1945). 
Empat (4) bulan kemudian, pemerintah merealisasikan amanat pasal 18 UUD 1945 dengan menerbitkan Undang-Undang Republik Indonesia Nomor 1 Tahun 1945. ${ }^{17}$ UU ini secara formal dipandang sebagai landasan hukum pertama pelaksanaan pemerintahan daerah di Indonesia, walaupun judul UU ini mengenai Pengaturan KNID, yang menimbulkan pro-kontra dalam penafsiran sebelum dibuatkan penjelasan resmi yang dikeluarkan Kementerian Dalam Negeri, dengan menegaskan beberapa hal mendasar, antara lain : Pertama, mengantisipasi pembentukan suatu badan (lembaga) bersifat sementara waktu sebelum diadakan pemilu, yang berfungsi sebagai Badan Perwakilan Rakyat (BPR) di daerah. Kedua, Badan Perwakilan Rakyat Daerah (BPRD) bersama dengan Kepala Daerah menjalankan pekerjaan mengatur rumah tangga daerahnya. Ketiga, Badan Executif yang dipimpin oleh kepala daerah berasal dan dipilih dari anggota KND yang berfungsi menjalankan pemerintahan sehari-hari. Keempat, Ketua Komite Nasional Indonesia yang lama dalam status yang baru menjadi Wakil Ketua Badan Executif dan anggota Badan Perwakilan Rakyat Daerah.

Kenyataannya, dalam perkembangan KNID tidak hanya sekedar membantu, tetapi secara nyata ikut menjalankan pemeritahan di daerah. ${ }^{18}$ Mengatasi masalah tersebut, maka pemerintah NKRI mengeluarkan Maklumat Wakil Presiden No. X tertanggal 16 Oktober 1945 memberikan landasan "penertiban" dengan cara mengatur kembali kedudukan KNID sesuai dengan kedudukan KNIP yang baru. Maklumat memuat unsur esensial : (1) Pembentukan BPRD dengan jalan merubah fungsi dan tugas KNID. (2) BPRD bersama-sama Kepala Daerah menjalankan pekerjaan mengatur rumah tangga daerahnya. (3) BPRD (terdiri dari sebanyakbanyaknya 5 orang) dipilih dari dan oleh anggota KNID sebagai "Badan Eksekutif" bersama-sama dan dipimpin oleh Kepala Daerah menjalankan pemerintahan seharihari (dibidang otonomi dan tugas pembantuan).

Daerah Otonom sebagai sarana persemaian otonomi dihidupkan kembali secara resmi, walaupun usaha ini terjebak oleh penetapan PPKI Tanggal 19 Agustus 1945, mengenai pembagian wilayah dan pembentukan susunan pemerintahan tingkat daerah yang dikategorikan sebagai daerah otonom. Propinsi, Kawedanan dan Kecamatan tetap semata-mata sebagai unsur dekonsentrasi dan tugas pembantuan

${ }^{17}$ UU ini dinamakan "Undang-Undang 1945 Nomor 1 Tentang Komite Nasional Daerah". Diumumkan dalam Berita Republik Indonesia Tahun II Nomor 7 halaman 56 kolom 1, ditetapkan di Jakarta Tanggal 23 Nopember 1945. hal. 246.

${ }^{18}$ A. H. Nasution, "Sekitar Perang Kemerdekaan Indonesia I", (Bandung: Angkasa, 1977), 
yang hanya menjadikan sebagai wilayah pemerintahan administratif. Dalam era ini, semakin kuat pada penguatan sentralisasi dan desentralisasi semakin terpinggirkan. Perpaduan politik desentralisasi dan dekonsentrasi sebagai sarana untuk mengantisipasi kemungkinan daerah-daerah melepaskan diri dari (pemerintah) pusat, sehingga dapat dapat membahayakan eksistensi NKRI. Kondisi dan konstalasi politik yang demikian, tidak dapat menghindari timbulnya dualisme dan tidak terpenuhinya amanat kaidah Pasal 18 UUD 1945, yang menghendaki dikedepankannya politik desentralisasi.

Seiring dengan perkembangan ketatanegaraan yang semakin kondusif, maka pemerintah menerbitkan Undang-Undang Republik Indonesia Nomor 22 Tahun 1948, yang mengatur perlunya penentuan batas-batas kewenangan daerah. ${ }^{19}$ UU ini lahir untuk mempertegas fungsi dan kedudukan DPD dan DPRD sebagai pelaksana pemerintahan daerah, sekaligus sebagai evaluasi dari pemberlakuan UU sebelumnya, yang memberikan ketidakjelasan batas kewenangan pemerintah daerah dan tidak berpihaknya pada aspek implementasi kedaulatan rakyat.

Sementara masa pmberlakuan Konstitusi Republik Indonesia Serikat Tahun 1949 sebagai hukum dasar negara melahirkan susunan negara federal, ${ }^{20}$ yang membawa konsekuensi atas pembagian wilayah (daerah) dalam struktur pemerintah negara federal, pemerintah negara bagian serta pemerintah daerah di bawahnya. Berdasarkan amanat yang termaktub dalam Konstitusi RIS. Pembagian kekuasan dalam pemerintahan negara federal ditentukan terlebih dahulu kekuasaan pada negara (daerah) bagian, kemudian kekuasaan yang dilimpahkan kepada pemerintah federal. Kedudukan daerah-daerah swapraja masuk dalam tugas dan kekuasaan daerah-daerah bagian. ${ }^{21}$

${ }^{19}$ UU ini dinamakan "Undang-Undang Republik Indonesia Nomor 22 Tahun 1948 Tentang Pemerintah Daerah". Diundangkan dalam Berita Republik Indonesia Tahun 1948 Nomor 7 halaman 56 kolom 1, yang ditetapkan di Yogyakarta pada Tanggal 10 Juli 1948.

${ }^{20}$ Lihat Konstitusi RIS, khususnya Pasal 1 (1) Republik Indonesia Serikat jang merdeka dan berdaulat ialah suatu Negara-hukum yang demokrasi dan berbentuk federasi.

${ }^{21}$ Lihat makna yang termaktub dalam Pasal 2 Konstitusi RIS 1949, ditegaskan bahwa RIS meliputi seluruh daerah Indonesia, yaitu daerah bersama: (a) Negara RI, dengan daerah menurut status quo seperti tersebut dalam persetujuan Renville Tanggal 17 Januari Tahun 1948, Negara Indonesia Timur, Negara Pasundan termasuk distrik federal Jakarta, Negara Jawa Timur, Negara Madura, Negara Sumatera Timur dengan pengertian bahwa status quo asahan selatan dan labuhan ratu berhubungan dengan negara sumatera timur tetap berlaku, Negara Sumatera Selatan. (b) Satuan kenegaraan yang tegak sendiri: Jawa Tengah, Bangka, Belitung, Riau, Kalimantan Barat (daerah istimewa), Dayak Besar, Daerah Banjar, Kalimantan Tenggara, Kalimantan Timur. 
Realisasi dari amanat Konstitusi RIS, untuk mengatur hubungan pemerintah negara bagian dengan pemerintah daerah maka dikeluarkanlah Undang-Undang Negara Indonesia Timur (UU NIT) Nomor 44 Tahun 1950 tentang Pemerintah Daerah Negara Indonesia Timur, ditetapkan pada tanggal 15 Mei 1950. UU ini terbit empat hari sebelum tercapai persetujuan dalam mengambil langkah-langkah kembali membentuk negara kesatuan dan sengaja ditetapkan untuk menyongsong pembentukan negara kesatuan untuk menyesuaikan susunan pemerintahan daerah dalam lingkungan wilayah Indonesia Timur dengan susunan negara kesatuan.

Pada dasarnya, kaidah yang terkandung dalam aturan ini secara keseluruhan sama dengan UU No. 22 Tahun 1948, kecuali dalam hal-hal sebagai berikut. (1) Susunan dan penamaan daerah dalam UU NIT No. 44 Tahun 1950 memungkinkan susunan terdiri atas 2 atau 3 tingkatan dengan nama: negara bagian, daerah bagian dan daerah anak bagian. (2) Sebutan resmi Dewan Pemerintahan Daerah adalah Dewan Pemerintah dan keanggotaannya diambil bukan dari anggota DPRD. (3) Jumlah anggota DPRD tidak semata-mata berdasarkan jumlah penduduk, juga mempertimbangkan luasnya otonomi, keuangan, suasana politik, dan masa jabatan. Dinamika yang terjadi pada tahun 1949 sampai tahun 1956 sangat menarik dikaji karena di satu bagian wilayah Republik Indonesia sebagai bagian dari negara RIS berlaku UU No. 22 Tahun 1948 dan di sisi lain, tepatnya kawasan Negara Indonesia Timur, berlaku UU NIT No. 44 Tahun 1950 dengan bentuk dan susunan yang berbeda.

Sedangkan pemberlakuan UUD Sementara Republik Indonesia Tahun 1950 sebagai hukum dasar negara melalui landasan hukum UU No. 7 Tahun 1950, yang ditandatangani oleh Presiden RIS pada tanggal 15 Agustus 1950 di Jakarta dan mulai berlaku pada 17 Agustus 1950. Perubahan ini disetujui seluruhnya dalam Sidang ke-I Babak ke-3 rapat ke-71 DPR RIS pada tanggal 14 Agustus 1950 di Jakarta, dewan yang diketuai oleh Soemardi dan sekretaris RIS oleh Sartono. ${ }^{22}$ UUDS 1950

${ }^{22}$ Lihat Naskah Persetujuan Pemerintah RIS dan Pemerintah RI yang ditetapkan pada hari Jum'at, 19 Mei 1950, oleh Perdana Menteri RIS Mohammad Hatta dan Perdana Menteri RI A. Halim. Pergantian konstitusi pada saat itu diawali oleh persetujuan antara perwakilan pemerintah RIS dan pemerintah RI dalam sidang (pertemuan) pada hari Jum'at, 9 Mei 1950, yang melahirkan beberapa kesepakatan penting, antara lain: (1) Menyetujui melaksanakan Negara Kesatuan sebagai jelmaan daripada RI berdasarkan Proklamasi 17 Agustus 1945. (2) Menyetujui pergantian Konstitusi RIS 1949 menjadi UUDS 1950 sebagai hukum dasar negara. (3) Untuk meratifikasi persetujuan ini, maka masing-masing, pemerintah RIS mengajukan kepada DPR dan senat, sedangkan pemerintah RI mengajukan kepada BP KNIP. Lihat makna yang termaktub dalam UUDS RI 1950, Khususnya Klausul Menimbang dan Mengingat. Konstitusi ini, dijadikan dasar perubahan landasan hukum 
mengubah susunan negara federal menjadi negara kesatuan, ${ }^{23}$ yang membawa konsekuensi makna hukum yang mengatur pelaksanaan pemerintahan di daerah.

Landasan hukum pelaksanaan pemerintah daerah termaktub dalam Pasal 131 yang memuat prinsip: 1. pembagian daerah Indonesia atas daerah besar dan kecil yang berhak mengatur dan mengurus rumah tangga sendiri (otonom). 2. bentuk dan susunan pemerintahannya ditetapkan dengan UU. 3. daerah-daerah diberikan autonomi seluas-luasnya untuk mengurus rumah tangganya sendiri. 4. dengan UU, dapat diserahkan penyelenggaraan tugas-tugas kepada daerah-daerah yang tidak termasuk dalam urusan rumah tangganya. Pasal 132 memuat prinsip kedudukan daerah-daerah swapraja diatur dengan UU. Pasal 133 memuat prinsip: sambil menunggu ketentuan baru, maka peraturan yang sudah ada tetap berlaku.

Realisasi amanat Pasal 131, 132, 133 UUDS, maka pemerintah menerbitkan Undang-Undang Republik Indonesia No. 1 Tahun 1957. ${ }^{24}$ sebagai landasan hukum pelaksanaan pemerintahan di daerah. Hal ini mendesak untuk dilakukan karena di satu sisi pemberlakuan UU No. 22 Tahun 1948 terbatas pada daerah tertentu (wilayah RI pada saat Indonesia berbentuk RIS) dan UU NIT No. 44 Tahun 1950 juga masih menjadi pegangan sementara di wilayah Indonesia lainnya (daerah Negara Indonesia Timur). UU No. 1 Tahun 1957 lebih menekankan aspek desentralisasi pelaksanaan pemerintahan di daerah, yang sebenarnya pernah diubah (ditambah) dengan UU No. 6 Tahun 1958 tentang Penetapan UU Darurat No. 6 Tahun 1957 (LN Tahun 1957 No. 9) tentang Perubahan UU Pokok-Pokok Pemerintahan Daerah 1956 sebagai Undang-Undang. Perubahan ini tidak mencabut pemberlakuan UU No. 1 Tahun 1957, tetapi hanya mengubah mengenai domisili calon-calon anggota legislatif bagi DPRD swatantra.

Sementara pemberlakuan UUD RI Tahun 1945 (Periode II - Dekrit Presiden RI) sebagai hukum dasar negara, melalui Dekrit Presiden RI yang dibingkai dalam Keppres No. 150 Tahun 1959 berisikan 3 hal pokok, yaitu : (1) pembubaran konstituante, (2) penetapan UUD 1945, dan (3) pembentukan MPRS serta

penyelenggaraan negara dan pemerintahan, yang senantiasa mendengar seluruh aspirasi elemen bangsa dalam menjaga keutuhan dan kesatuan Negara RI.

${ }^{23}$ Lihat makna yang termaktub dalam UUDS 1950 Pasal 1 ayat (1) Republik Indonesia yang merdeka dan berdaulat ialah suatu Negara-Hukum yang demokratis dan berbentuk kesatuan.

${ }^{24}$ UU ini dinamakan "Undang-Undang Republik Indonesia Nomor 1 Tahun 1957 Tentang Pokok-Pokok Pemerintahan Daerah". Diundangkan dalam Lembaran Negara Republik Indonesia Tahun 1957 Nomor 6, yang ditetapkan di Jakarta pada Tanggal 17 Januari 1957 oleh Presiden RI Soekarno dengan Persetujuan Dewan Perwakilan Rakyat, dan diundangkan oleh Menteri Kehakiman "Soenarjo" pada Tanggal 18 Januari 1957. 
pembentukan DPAS. UUD 1945 yang diberlakukan kembali sebagai hukum dasar negara menuntut dilakukannya penyesuaian sesuai amanat yang termaktub dalam kaidah Pasal 18 sebagai jiwa pelaksanaan Pemerintahan Daerah. Realisasi dari amanat tersebut, maka pemerintah menerbitkan Penetapan Presiden Republik Indonesia (Pen-Pres) Nomor 6 Tahun 1959, ${ }^{25}$ sebagai usaha pemerintah dalam melanjutkan politik desentralisasi dan dekonsentrasi dan berusaha menghilangkan dualisme pimpinan pemerintahan di daerah. Hal ini berkaitan dengan program politik pemerintah dalam melaksanakan "demokrasi terpimpin" dalam rangka kembali kepada UUD $1945 .^{26}$

Penpres ini dikenal sebagai aturan penyempurnaan dari UU No. 1 Tahun 1957, yang dapat dilihat dalam beberapa hal: (1) Menghilangkan dualisme pemerintahan di daerah antara fungsi otonomi dan fungsi kepamongprajaan. (2) Penyempurnaan Bentuk, susunan, kekuasaan, tugas, dan kewajiban pemerintah daerah. (3) Menghilangkan bahaya persatuan dan kesatuan serta keselamatan negara, nusa dan bangsa. (4) Menghilangkan aspek yang bisa merintangi pembangunan, baik di tingkat pusat maupun di tingkat daerah. (5) Memperbesar pengendalian pusat terhadap daerah. Dualisme pemerintahan di daerah dihilangkan dengan jalan menetapkan kembali kepala daerah sebagai alat pusat dan alat daerah. Kepala daerah berdiri sendiri dan menjadi pimpinan sehari-hari penyelenggaraan pemerintahan di daerah, tidak bertanggung jawab kepada DPRD dan tidak dapat dijatuhkan oleh DPRD. ${ }^{27}$

${ }^{25}$ Penpres ini dinamakan "Penetapan Presiden Republik Indonesia Nomor 6 Tahun 1959 Tentang Pemerintah Daerah (Disempurnakan)". LN RI Tahun 1959 Nomor 94, ditetapkan di Bogor pada Tanggal 7 Nopember 1959 oleh Presiden RI Soekarno dengan Persetujuan (tidak jelas), dan diundangkan di Jakarta oleh Menteri Muda Kehakiman "Soekarjo" pada Tanggal 16 Nopember 1959. Ada juga beberapa buku menunjuk pada ditetapkan di Tanjung Pinang tanggal 7 Nopember 1959.

${ }^{26}$ Lihat Putusan Dewan Menteri mengenai Pelaksanaan Demokrasi Terpimpin dalam Rangka Kembali Ke UUD 1945 diputuskan dalam sidang Dewan Menteri pada Tanggal 19 Pebruari 1959 di Jakarta.

27 Kenyataan menunjukkan, bahwa penpres ini berseberangan dengan kehendak penyempurnaan, yang dapat dilihat dalam: (1) Pengawasan pusat atas jalannya pemerintahan daerah semakin kuat dan ketat yang membuat biasnya pelaksanaan otonomi. (2) Kepala daerah sebagai alat pusat mempunyai kekuasaan untuk mempertangguhkan keputusan DPRD, apabila dipandang bertentangan GBHN, kepentingan umum dan peraturan perundang-undangan yang lebih tinggi tingkatnya. (3) Kepala daerah diangkat oleh Presiden untuk Dati I dan Mendagri atas persetujuan Presiden untuk Dati II. Presiden atau Mendagri dengan persetujuan Presiden dapat mengangkat kepala 
Pada dekade 1960-an, tuntutan revisi landasan hukum pemerintahan daerah semakin kuat, yang akhirnya dikeluarkanlah Undang-Undang Republik Indonesia Nomor 18 Tahun $1965 .^{28}$ UU ini semakin memperkuat kedudukan kepala daerah dengan tujuan untuk menjamin kelangsungan kesatuan negara, dimana DPRD bertangung jawab kepada kepala daerah. Di tengah pemberlakuan UU ini, terjadi perubahan yang dramatis dalam perjalanan ketatanegaraan NKRI, dengan turunnya Presiden Soekarno dari puncak kekuasaan dan pengangkatan Jenderal Soeharto sebagai Penjabat Presiden RI dalam Sidang Umum MPRS Tahun 1966.

Disamping pergantian pimpinan nasional, SU MPRS juga meletakkan berbagai kebijaksanaan dasar, yang diatur dalam beberapa ketetapan antara lain : (1) Kedudukan Lembaga Negara tingkat pusat dan daerah yang diatur dalam UUD 1945. (2) Peninjauan kembali produk-produk legislatif negara di luar produk MPRS yang Tidak Sesuai dengan UUD 1945. (3) Sumber Tertib Hukum dan Tata Urutan Peraturan Perundang-undangan Republik Indonesia. (4) Pemberian Otonomi Seluasluasnya kepada Daerah. (5) Pembaharuan Kebijaksanaan Landasan Ekonomi, Keuangan dan Pembangunan. ${ }^{29}$

Sembilan (9) tahun kemudian, setelah terjadi peralihan kekuasaan dari Ir. Soekarno kepada Jenderal Soeharto, maka pemerintah menerbitkan UndangUndang Republik Indonesia Nomor 5 Tahun $1974^{30}$ yang mengatur mengenai pemerintahan daerah otonom dan susunan pemerintahan wilayah administratif. UU

daerah di luar calon yang diajukan oleh DPRD. Jadi, kewenangan daerah (DPRD) untuk menentukan pimpinan daerahnya tidak ada lagi.

28 UU RI No. 18 Tahun 1965 dinamakan "Pokok-Pokok Pemerintahan Daerah". Diundangkan dalam LN RI Tahun 1965 Nomor 83 dan TLN RI Nomor 2778, yang ditetapkan di Jakarta pada Tanggal 1 September 1965 oleh Presiden RI Soekarno dengan Persetujuan Dewan Perwakilan Rakyat Gotong Royong, dan diundangkan di Jakarta oleh Sekretaris Negara "Moh. Ichsan" pada Tanggal 1 September 1965.

${ }^{29}$ Lihat Tap MPRS No. XX/MPRS/1966 tentang Memorandum DPRGR mengenai Sumber Tertib Hukum Republik Indonesia dan Tata Urutan Peraturan Perundang-undangan Republik IndonesiaLihat Tap No. XXI/MPRS/1966 tentang Pemberian Otonomi Seluas-luasnya kepada Daerah. Lihat Tap No. XXII/MPRS/1966 tentang Pembaharuan Kebijaksanaan Landasan Ekonomi, Keuangan dan Pembangunan.

${ }^{30}$ UU No.5 Tahun 1974 dinamakan 'Pokok-Pokok Pemerintahan Di Daerah". Diundangkan dalam LN RI Tahun 1974 Nomor 38 dan TLN RI Nomor 3037, yang ditetapkan di Jakarta pada Tanggal 23 Juli 1974 oleh Presiden RI Soeharto dengan Persetujuan (tidak jelas), dan diundangkan di Jakarta oleh Menteri/Sekretaris Negara "Sudharmono, SH" pada Tanggal 23 Juli 1974. UU No. 5 Tahun 1974. 
ini menguatkan (dominan) asas dekonsentrasi untuk menciptakan stabilitas yang kuat dalam upaya pembangunan ekonomi. Kontrol pemerintah pusat kepada daerah semakin kuat sehingga membuat fungsi dan peranan daerah sebagai perpanjangan tangan untuk menyukseskan program-program yang dirancang pemerintah pusat. Dominasi pusat yang kuat ini secara langsung dapat menciptakan stabilitas pembangunan nasional, tetapi di lain pihak membuat ketergantungan daerah yang sangat tinggi kepada pemerintah pusat.

Tahun 1998 dinamika ketatanegaraan kembali terjadi, dengan bergulirnya reformasi yang akhirnya memaksa terjadinya peralihan kekuasaan dari Soeharto ke BJ. Habibie. Amanat reformasi menuntut perhatian pemerintah untuk melakukan penyesuaian berbagai undang-undang organik sebagai penjabaran dari UUD. Di bawah Presiden Habibie, pemerintah menerbitkan Undang-Undang Republik Indonesia Nomor 22 Tahun $1999^{31}$ yang secara langsung menjawab harapan masyarakat (daerah) dalam merevisi UU No. 5 Tahun 1974. Kelahiran UU ini diharapkan dapat mengakomodir perubahan paradigma pemerintahan, dari yang sentralistis menjadi desentralistis, mengedepankan prinsip demokrasi, pemerataan dan keadilan, memperhatikan perbedaan dan keanekaragaman, serta dapat mencegah terjadinya disintegrasi bangsa.

Kaidah UU ini mencerminkan semangat radical change dalam 5 (lima) pikiran dasar, yaitu: Pertama, sebagai upaya mewujudkan otonomi daerah dengan memberikan keleluasan kepada daerah untuk menjadikan daerah otonom yang mandiri. Kedua, penyelenggaraan otonomi yang luas di atas prinsip-prinsip demokrasi, pemerataan dan keadilan, serta memperhatikan potensi dan keanekaragaman daerah. Ketiga, meningkatkan peran dan fungsi DPRD sebagai badan legislatif daerah dan badan pengawas sebagai sarana pengembangan demokrasi serta mendudukkan kesejajaran dan kemitraan antar kepala daerah dan DPRD dalam menyelenggarakan pemerintahan daerah. Keempat, untuk mengantisipasi perkembangan keadaan, baik di dalam negeri maupun tantangan persaingan global yang mau tidak mau pengaruhnya akan melanda daerah. Kelima, untuk mendudukkan kembali posisi desa sebagai kesatuan masyarakat hukum terendah yang memiliki hak asal-usul dan otonomi asli yang diakui dan dihormati dalam sistem pemerintahan NKRI.

${ }^{31}$ UU No. 22 Tahun 1999 tentang "Pemerintahan Daerah". Diundangkan dalam LN RI Tahun 1999 Nomor 60 dan TLN RI Nomor 3839, yang ditetapkan di Jakarta pada Tanggal 07 Mei 1999 oleh Presiden RI Bachruddin Jusuf HabibieJ dengan Persetujuan Dewan Perwakilan Rakyat, dan diundangkan di Jakarta oleh Menteri Sekretaris Negara RI "Akbar Tandjung" pada Tanggal 7 Mei 1999. 
Di tengah-tengah pemberlakuan UU ini, guliran konsep amandemen terhadap UUD 1945 berjalan seiring dengan semakin menguatnya krisis kepercayaan sebagian elemen masyarakat terhadap profil pimpinan nasional. Pemerintah di bawah pimpinan Presiden Habibie dan parlemen melahirkan suatu kesepakatan untuk memulai proses amandemen dalam empat tahapan (mulai Tahun 1999 s/d 2002). Setelah amandemen UUD 1945 rampung dilaksanakan dan ditetapkan secara menyeluruh, maka penamaan UUD 1945 berubah menjadi UUD Negara Republik Indonesia Tahun 1945.

Setelah UUD NRI Tahun 1945 (Periode III-Amandemen UUD) ditetapkan sebagai hukum dasar negara, secara langsung turut mempengaruhi landasan pelaksanaan pemerintahan di daerah. Kaidah konstitusi yang menjiwai penyelenggaraan pemerintahan daerah berbeda pemaknaannya dengan pemberlakuan UUD sebelumnya. Perubahan dapat dilihat dalam: Pertama, pemerintah daerah yang diatur dalam kaidah Pasal 18 UUD RI Tahun 1945 masih abstrak karena hanya secara tersurat dalam kata "daerah besar dan kecil" dengan "bentuk susunan pemerintahannya”. Sementara, UUD NRI Tahun 1945 termaktub dalam Pasal 18 ayat (1) lebih jelas tersurat dengan kata "daerah Provinsi, daerah kabupaten dan kota", "mengatur dan mengurus sendiri", "asas otonomi dan tugas pembantuan", "memiliki DPRD", "menjalankan otonomi seluas-luasnya", serta "menetapkan peraturan daerah dan peraturan-peraturan lain”. Kedua, UUD NRI Tahun 1945 mengubah (menambah) Pasal 18 menjadi 3 pasal, yaitu dalam Pasal 18A mengenai hubungan wewenang dan keuangan dan Pasal 18B mengenai pengakuan kekhususan dan keistimewaan daerah.

Realisasi amanat kaidah Pasal 18 UUD NRI 1945 setelah diamandemen diperluas (ditambah) dengan 2 pasal, sehingga kaidah yang terkandung di dalamnya turut berubah dan harus dilakukan penyesuaian. Untuk itu, pemerintah di bawah Presiden Megawati (yang sebelumnya wakil dari Presiden Abdurahman Wahid), menerbitkan Undang-Undang Republik Indonesia Nomor 32 Tahun 2004 sebagai landasan hukum pemerintahan daerah, ${ }^{32}$ yang menekankan supaya pemerintah daerah dapat mengatur dan mengurus sendiri urusan pemerintahan di daerahnya menurut asas otonomi dan tugas pembantuan, yang diarahkan untuk mempercepat terwujudnya kesejahteraan masyarakat dengan memperhatikan prinsip demokrasi,

${ }^{32}$ UU Nomor 32 Tahun 2004 dinamakan "Undang-Undang Republik Indonesia Nomor 32 Tahun 2004 Tentang Pemerintahan Daerah", dalam LN RI Tahun 2004 Nomor 125 dan TLN RI Nomor 4437, ditetapkan di Jakarta pada Tanggal 15 Oktober 2004 oleh Presiden RI Megawati Soekarnoputri dengan Persetujuan DPR, dan diundangkan di Jakarta oleh Menteri Sekretaris Negara RI "Bambang Kesowo" Tanggal 15 Oktober 2004. 
pemerataan, keadilan, keistimewaan dan kekhususan suatu daerah dalam sistem NKRI.

Hukum dasar negara yang (pernah) berlaku sampai sekarang secara positif dan pergantian peraturan perundang-undangan yang mengatur secara lansung pemerintahan di daerah, turut berpengaruh lansung dalam mewujudkan pelaksanaan otonomi di daerah. Pergantian (perubahan) landasan hukum pelaksanaan pemerintahan daerah dari Tahun 1945 sampai sekarang dapat dilihat dalam tabel di bawah ini:

Tabel 1

Dasar Hukum Pelaksanaan Pemerintahan Daerah dalam Beberapakali Pergantian (Perubahan) Hukum Dasar Negara

\begin{tabular}{|c|c|c|c|c|}
\hline Konstitusi/ UUD & Dasar Hukum & Pemberlakuan & Pasal & UU Organik \\
\hline $\begin{array}{l}\text { UUD Tahun } 1945 \\
\text { (Periode Pertama) }\end{array}$ & $\begin{array}{l}\text { Penetapan PPKI Tgl. } \\
\text { 18/8/1945, Proklamasi } \\
\text { NKRI Tanggal 17/8/1945 }\end{array}$ & $\begin{array}{c}\text { Mulai Tanggal } \\
18 / 8 / 1945 \mathrm{~s} / \mathrm{d} \\
7 / 12 / 1949\end{array}$ & $\begin{array}{l}\text { Pasal } 18 \text { dan } \\
\text { Penjelasan }\end{array}$ & $\begin{array}{l}\text { UU No. } 1 / 1945 \\
\text { UU No. } 22 / 1948\end{array}$ \\
\hline $\begin{array}{l}\text { Konstitusi Sementara } \\
\text { RIS Tahun } 1949\end{array}$ & $\begin{array}{l}\text { Persetujuan Renville (KMB) } \\
\text { Tgl } 17 \text { Januari Tahun } 1948\end{array}$ & $\begin{array}{c}\text { Mulai Tanggal } \\
27 / 12 / 1949 \mathrm{~s} / \mathrm{d} \\
17 / 8 / 1950\end{array}$ & $\begin{array}{c}\text { Pasal } 43 \\
\text { sampai Pasal } \\
67\end{array}$ & $\begin{array}{l}\text { UU NIT No.44/1950 } \\
\text { (UU No. 22/ 1948) }\end{array}$ \\
\hline $\begin{array}{l}\text { UUD Sementara Tahun } \\
1950\end{array}$ & $\begin{array}{l}\text { Persetujuan RIS dgn RI dgn } \\
\text { dasar UU No. } 7 \text { Tahun } 1950\end{array}$ & $\begin{array}{c}\text { Mulai Tanggal } \\
17 / 8 / 1950 \mathrm{~s} / \mathrm{d} \\
5 / 7 / 1959\end{array}$ & $\begin{array}{c}\text { Pasal 131, } \\
132,133\end{array}$ & UU No. $1 / 1957$ \\
\hline $\begin{array}{l}\text { UUD Tahun } 1945 \\
\text { (Periode Kedua) }\end{array}$ & $\begin{array}{l}\text { Dekrit Presiden RI dgn } \\
\text { Dasar Keppres No. } 150 \\
\text { Tahun } 1959\end{array}$ & $\begin{array}{c}\text { Mulai Tanggal } \\
5 / 7 / 1959 \mathrm{~s} / \mathrm{d} \\
19 / 10 / 1999\end{array}$ & $\begin{array}{l}\text { Pasal } 18 \text { dan } \\
\text { Penjelasan }\end{array}$ & $\begin{array}{c}\text { Penpres No.6/1959 } \\
\text { (UU No.1/1957) } \\
\text { UU No. } 18 / 1965 \\
\text { UU No. } 5 / 1974 . \\
\text { UU No. } 22 / 1999\end{array}$ \\
\hline $\begin{array}{l}\text { UUD NRI Tahun } 1945 \\
\text { (Periode Ketiga) }\end{array}$ & $\begin{array}{l}\text { Amandemen UUD mulai } \\
\text { Tahun } 1999 \text { - Tahun } 2002\end{array}$ & $\begin{array}{l}\text { Mulai Tanggal } \\
19 / 10 / 1999 \mathrm{~s} / \mathrm{d} \\
\text { sekarang }\end{array}$ & $\begin{array}{l}\text { Pasal 18, } \\
18 \mathrm{~A}, 18 \mathrm{~B}\end{array}$ & $\begin{array}{l}\text { UU No. } 22 / 1999 \\
\text { UU No. } 32 / 2004\end{array}$ \\
\hline
\end{tabular}

Sumber data: Analisis pemberlakuan dan perubahan (pergantian) hukum dasar negara di NKRI dari Tahun 1945 sampai dengan sekarang, serta data Arsip Nasional dan Perpustakaan Nasional Rl.

Tabel 2

Perubahan (Pergantian) Landasan Hukum Pelaksanaan Pemerintahan (di) Daerah dari Tahun 1945 sampai Tahun 2005

\begin{tabular}{|c|l|l|c|}
\hline No & UU/Penpres & \multicolumn{1}{|c|}{ Penamaan \& Pengundangan } & Pemberlakuan \\
\hline 1. & UU RI Nomor 1 & "KOMITE NASIONAL DAERAH", Berita Republik Indonesia \\
Tahun 1945 & $\begin{array}{l}\text { Tahun II Nomor 7 halaman 56 kolom 1, ditetapkan di Jakarta } \\
\text { Tanggal 23 Nopember 1945 oleh Presiden RI Soekarno } \\
\text { Persetujuan BP KNP, dan diumumkan oleh Sekretaris Negara } \\
\text { "A.G. Pringgodigdo" Tanggal 23 Nopember 1945. }\end{array}$ & $\begin{array}{c}\text { Mulai Tanggal } \\
23 / 11 / 45 \\
\text { s/dTanggal 9/7/48 }\end{array}$ \\
\hline 2. & $\begin{array}{l}\text { UU RI Nomor } \\
\text { 22 Tahun 1948 }\end{array}$ & $\begin{array}{l}\text { "PEMERINTAH DAERAH", Berita Republik Indonesia Tahun } \\
\text { 1948 Nomor 7 halaman 56 kolom 1, ditetapkan di Yogyakarta } \\
\text { Tanggal 10 Juli 1948 oleh Presiden RI Soekarno Persetujuan }\end{array}$ & $\begin{array}{c}\text { Mulai Tanggal } \\
10 / 7 / 48 \text { s/dTanggal } \\
17 / 1 / 57\end{array}$ \\
\hline
\end{tabular}




\begin{tabular}{|c|c|c|c|}
\hline & & $\begin{array}{l}\text { BP KNP, diumumkan oleh Wakil Sekretaris Negara "Ratmoko" } \\
\text { pada Tanggal } 10 \text { Juli } 1948 .\end{array}$ & \\
\hline 3. & $\begin{array}{l}\text { UU NIT Nomor } \\
44 \text { Tahun } 1950\end{array}$ & $\begin{array}{l}\text { "PEMERINTAH DAERAH INDONESIA TIMUR" Diumumkan } \\
\text { (diterbitkan) tiga hari sebelum berlakunya UUDS Tahun } 1950\end{array}$ & $\begin{array}{c}\text { Mulai Tanggal } \\
15 / 5 / 50 \mathrm{~s} / \mathrm{dTanggal} \\
17 / 8 / 50\end{array}$ \\
\hline 4. & $\begin{array}{l}\text { UU RI Nomor } 1 \\
\text { Tahun } 1957\end{array}$ & $\begin{array}{l}\text { "POKOK-POKOK PEMERINTAHAN DAERAH", LN RI Tahun } \\
1957 \text { Nomor 6, yang ditetapkan di Jakarta pada Tanggal } 17 \\
\text { Januari } 1957 \text { oleh Presiden RI Soekarno Persetujuan DPR, dan } \\
\text { diundangkan oleh Menteri Kehakiman "Soenarjo" pada Tanggal } \\
\text { 18 Januari } 1957 .\end{array}$ & $\begin{array}{c}\text { Mulai Tanggal } \\
18 / 1 / 57 \text { s/dTanggal } \\
8 / 9 / 59\end{array}$ \\
\hline 5. & $\begin{array}{l}\text { Pen-Pres RI } \\
\text { Nomor } 6 \text { Tahun } \\
1959\end{array}$ & $\begin{array}{l}\text { "PEMERINTAH DAERAH (DISEMPURNAKAN)", LN RI Tahun } \\
1959 \text { Nomor 94, ditetapkan di Bogor Tanggal } 7 \text { Nopember } 1959 \\
\text { oleh Presiden RI Soekarno Persetujuan (tidak jelas), } \\
\text { diundangkan oleh Menteri Muda Kehakiman "Soekarjo" Tanggal } \\
16 \text { Nopember } 1959 \text {. }\end{array}$ & $\begin{array}{c}\text { Mulai Tanggal } \\
\text { 9/9/59 s/d Tanggal } \\
31 / 8 / 65\end{array}$ \\
\hline 6. & $\begin{array}{l}\text { UU RI Nomor } \\
18 \text { Tahun } 1965\end{array}$ & $\begin{array}{l}\text { "POKOK-POKOK PEMERINTAHAN DAERAH", LN RI Tahun } \\
1965 \text { Nomor } 83 \text { dan TLN RI Nomor } 2778 \text {, yang ditetapkan di } \\
\text { Jakarta pada Tanggal } 1 \text { September } 1965 \text { oleh Presiden RI } \\
\text { Soekarno Persetujuan DPRGR, dan diundangkan di Jakarta } \\
\text { oleh Sekretaris Negara "Moh. Ichsan" pada Tanggal } 1 \\
\text { September } 1965 .\end{array}$ & $\begin{array}{c}\text { Mulai Tanggal } \\
1 / 9 / 65 \text { s/d Tanggal } \\
22 / 7 / 74\end{array}$ \\
\hline 7. & $\begin{array}{l}\text { UU RI Nomor } 5 \\
\text { Tahun } 1974\end{array}$ & $\begin{array}{l}\text { "POKOK-POKOK PEMERINTAHAN DI DAERAH" } \\
\text { LN RI Tahun } 1974 \text { Nomor } 38 \text { dan TLN RI Nomor } 3037 \text {, } \\
\text { ditetapkan di Jakarta Tanggal } 23 \text { Juli } 1974 \text { oleh Presiden RI } \\
\text { Soeharto Persetujuan DPR, diundangkan di Jakarta oleh } \\
\text { Menteri/Sekretaris Negara "Sudharmono, SH" pada Tanggal } 23 \\
\text { Juli } 1974 \text {. }\end{array}$ & $\begin{array}{c}\text { Mulai Tanggal } \\
\text { 23/7/74 s/d Tanggal } \\
6 / 5 / 99\end{array}$ \\
\hline 8. & $\begin{array}{l}\text { UU RI Nomor } \\
22 \text { Tahun } 1999\end{array}$ & $\begin{array}{l}\text { "PEMERINTAHAN DAERAH", LN RI Tahun } 1999 \text { Nomor } 60 \\
\text { dan TLN RI Nomor 3839, yang ditetapkan di Jakarta pada } \\
\text { Tanggal } 07 \text { Mei } 1999 \text { oleh Presiden RI Bachruddin Jusuf } \\
\text { HabibieJ Persetujuan DPR, dan diundangkan di Jakarta oleh } \\
\text { Menteri Sekretaris Negara RI "Akbar Tandjung" pada Tanggal } 7 \\
\text { Mei } 1999 \text {. }\end{array}$ & $\begin{array}{c}\text { Mulai Tanggal } \\
7 / 5 / 99 \text { s/d Tanggal } \\
14 / 10 / 04\end{array}$ \\
\hline 9. & $\begin{array}{l}\text { UU RI Nomor } \\
32 \text { Tahun } 2004\end{array}$ & $\begin{array}{l}\text { "PEMERINTAHAN DAERAH", LN RI Tahun } 2004 \text { Nomor } 125 \\
\text { dan TLN RI Nomor 4437, ditetapkan di Jakarta pada Tanggal } \\
15 \text { Oktober } 2004 \text { oleh Presiden RI Megawati Soekarnoputri } \\
\text { Persetujuan DPR, dan diundangkan di Jakarta oleh Menteri } \\
\text { Sekretaris Negara RI "Bambang Kesowo" pada Tanggal } 15 \\
\text { Oktober } 2004 \text {. }\end{array}$ & $\begin{array}{l}\text { Mulai Tanggal } \\
15 / 10 / 2004 \text { s/d } \\
\text { Sekarang }\end{array}$ \\
\hline
\end{tabular}

Sumber Data : Analisis Peraturan Perundang-undangan yang mengatur secara lansung Pelaksanaan Pemerintahan (di) Daerah dari Tahun 1945 sampai Tahun 2006.

\section{Pergeseran Makna Dalam Kaidah Hukum Dasar Negara}

Pemberlakuan secara positif hukum dasar negara dalam perjalanan NKRI, telah mengalami "lima kali" pergantian dan/atau "tiga kali" perubahan dengan substansi kaidah yang berbeda dalam penafsiran maknanya. Realisasi yang terjadi dalam 
kenyataannya, membawa konsekuensi pemaknaan dalam kaidahnya mengalami pergeseran sifat dan makna yang diaturnya, situasi dan kondisi yang turut mempengaruhinya (baik sisi hukum maupun politik), dan penjabaran amanat konstitusi dalam penerbitan peraturan sebagai pelaksanaan dalam implementasinya.

\section{Penafsiran Kaidah Bentuk dan Susunan Negara}

UUD RI 1945 (Proklamasi-Dekrit) menegaskan dalam kaidah "bentuk negara republik dengan susunan kesatuan....", sementara Konstitusi RIS 1949 menegaskan dalam kaidah "susunan federal yang berbentuk republik...", sedangkan UUDS RI 1950 menegaskan dalam kaidah "susunan kesatuan berbentuk republik...", dan UUD NRI 1945 (Amandemen) menegaskan dalam kaidah "susunan kesatuan yang berbentuk republik...".33 Dari kelima hukum dasar negara yang (pernah) berlaku positif sekarang, memberikan pergeseran makna yang termaktub di dalamnya, yaitu: UUD RI 1945 (Proklamasi-Dekrit), UUDS 1950 dan UUD NRI 1945 (Amandemen) memberikan penafsiran yang sama mengenai "Bentuk Negara Republik dengan Susunan Negara Kesatuan", tetapi Konstitusi RIS 1949 memberikan penafsiran bahwa RIS dalam "Bentuk Negara Republik dengan Susunan Negara Serikat". Perbedaan dalam kaidahnya, memberikan arti terjadinya pergeseran dalam makna hukum, yaitu: dari kaidah kesatuan beralih ke federal kemudian kembali kesatuan, membawa perubahan mendasar dalam perjalanan NKRI.

\section{Penafsiran Kaidah Bentuk dan Susunan Pemerintahan Daerah.}

Bentuk dan susunan pemerintahan daerah saat pemberlakuan secara positif Konstitusi/UUD sebagai Hukum Dasar Negara, terjadi pergeseran makna, antara lain: Kaidah Pasal 18 UUD RI 1945 (Proklamasi-Dekrit) memberikan penafsiran dalam: Pemerintah (Pusat), Pemerintah Daerah Besar/Propinsi (baik yang bersifat Istimewa, Otonom, Administratif), Pemerintah Daerah Kecil/Lebih Kecil Propinsi (baik yang bersifat Istimewa, Otonom, Administratif). Sementara dalam Kaidah Konstitusi RIS Tahun 1949, memberikan penafsiran dalam: Pemerintah Federal, Pemerintah Negara Bagian, Pemerintah Satuan Kenegaraan, Pemerintah Daerah Bagian,

${ }^{33}$ Lihat makna yang termaktub dalam Pasal 1 UUD RI 1945 Lihat makna yang termaktub dalam Pasal 1 KONSTITUSI RIS 1949. Lihat makna yang termaktub dalam Pasal 1 UUD SEMENTARA 1950. Lihat makna yang termaktub dalam Pasal 1 UUD NRI 1945. 
Pemerintah Daerah Anak Bagian, Pemerintah Daerah Istimewa. Sedangkan dalam Kaidah Pasal 131, 132 dan 133 UUDS RI 1950 memberikan penafsiran dalam: Pemerintah Pusat, Pemerintah Daerah Besar, Pemerintah Daerah Kecil, Pemerintah Daerah Swapraja. Kaidah Pasal 18 UUD NRI TAHUN 1945 (Amandemen) memberikan penafsiran dalam: Pemerintah Pusat, Pemerintah Daerah Propinsi, Pemerintah Daerah Kabupaten dan Pemerintah Daerah Kota.

Penafsiran dalam Kaidah hukum dasar negara tersebut, terjadi pergeseran makna dalam pemberlakuannya, antara lain: Pertama, kaidah UUD RI 1945 dan kaidah UUDS 1950 memberikan bentuk susunan pemerintahan dalam dua tingkatan, yaitu: pemerintahan daerah di daerah besar dan di daerah kecil, tetapi kaidah UUD RI 1945 lebi jelas dengan merinci pemerintahan daerah dalam pemerintahan daerah propinsi (daerah besar) baik yang bersifat otonom (ada BPD) dan bersifat administratif. Kedua, kaidah UUD NRI 1945 lebih jelas lagi dibandingkan dengan UUD RI 1945 dan UUDS 1950, karena dalam kaidahnya lebih menegaskan dengan rinci mengenai pemerintahan daerah propinsi, pemerintahan daerah kabupaten dan pemerintahan daerah kota. Ketiga, kaidah Konstitusi RIS 1949 berbeda dalam mengatur susunan pemerintahan di daerah, karena struktur dan susunan negara dalam kaidahnya menganut susunan federal, sehingga bentuk dan susunan pemerintahan di kenal pemerintahan negara bagian, daerah bagian, daerah anak bagian dan daerah di bawahnya lagi.

\section{Penafsiran Kaidah Struktur dan Tingkatan Daerah, Jenis dan Sifat Daerah}

UUD RI Tahun 1945 (Proklamasi-Dekrit) menegaskan: tingkatan dalam daerah besar (propinsi) dan daerah kecil (lebih kecil dari propinsi), sementara sifat, jenis dan istilah daerah dalam: daerah otonom, administratif dan istimewa. Sementara Konstitusi RIS Tahun 1949 menegaskan: Negara-negara bagian, Satuan-Satuan Kenegaraan yang tegak sendiri, daerah-daerah yang bukan daerah-daerah bagian. Disisi lain UUDS RI Tahun 1950 menegaskan: daerah besar dan daerah kecil, sementara sifat, jenis dan istilah daerah dalam: daerah otonom, istimewa dan swapraja. Sedangkan UUD NRI Tahun 1945 (Amandemen) menegaskan: provinsi, kabupaten, kota, sementara sifat dan jenis 
dalam: daerah otonom, wilayah administratif, daerah istimewa dan daerah khusus. $^{34}$

Dari penafsiran makna kaidah masing-masing hukum dasar negara, maka terjadi pergeseran makna, yaitu: Pertama, secara eksplisit UUD RI 1945, UUDS 1950, UUD NRI 1945 memberikan klasifikasi tingkatan yang sama: Daerah Besar dan Daerah Kecil, tetapi dalam penjelasan UUD RI 1945 merinci lagi dalam tingkatan Daerah Propinsi dan Daerah lebih kecil dari Propinsi, lebih dipertegas lagi dalam kaidah UUD NRI 1945 seperti Daerah Propinsi, Daerah Kabupaten dan Daerah Kota. Sementara Konstitusi RIS 1949 memberikan klasifikasi dalam tingkatan daerah: Negara Bagian, Satuan Kenegaraan, Daerah Bagian (bukan Negara Bagian dan Satuan Kenegaraan) serta Daerah Anak Bagian. Pergeseran kaidah ini memberikan konsekuensi banyaknya struktur dan tingkatan daerah yang mempunyai susunan pemerintahan tersendiri dalam pelaksanaan pemerintahan di daerah. Kedua, secara ekplisit UUD RI 1945, UUDS 1950 dan UUD NRI 1945 memberikan klasifikasi sifat dan jenis daerah yang sama : Daerah Otonom dan Daerah Istimewa, tetapi UUD RI menambah dengan Daerah Administratif, dan UUDS menambah Daerah Swapraja, serta UUD NRI 1945 menambah Daerah Khusus dan wilayah administratif. Sedangkan Konstitusi RIS memberikan klasifikasi sifat dan jenis dalam Daerah (negara bagian) yang berdiri sendiri dan daerah yang tidak berdiri sendiri. Pergeseran kaidah ini, memberikan konsekuensi secara lansung terhadap kewenangan pemerintahan daerah, baik kewenangan di bidang otonomi, dekonsentrasi dan tugas pembantuan atau akan tercipta daerah yang mempunyai (tidak mempunyai) kewenangan tersendiri dalam mengatur dan mengurus rumah tangganya sendiri, disamping mengurus urusan pemerintah pusat yang ada di daerah.

\section{Penafsiran Kaidah Prosedur dan Mekanisme Pendelegasian Kewenangan}

Kaidah masing-masing konstitusi yang berlaku (pernah) positif sebagai hukum dasar negara, terjadi pergeseran makna dalam mekanisme pendelegasian kewenangan, yaitu: Pertama, UUD RI 1945 (Proklamasi-

${ }^{34}$ Lihat makna yang termaktub dalam UUD RI 1945 Pasal 18 dan Penjelasan. Lihat makna yang termaktub dalam KONSTITUSI RIS 1949 Pasal 2, Pasal 42 sampai Pasal 54. Lihat makna yang termaktub dalam UUDS 1950 RI Pasal 131, Pasal 132 dan Pasal 133. Lihat makna yang termaktub dalam Kaidah UUD NRI 1945 Pasal 18, Pasal 18A dan Pasal 18B.. 
Dekrit), menegaskan mekanisme pendelegasian kewenangan "tidak termaktub secara atributori" dalam kaidahnya dan hanya memberikan penegasan: bahwa bentuk susunan pemerintahannya ditetapkan dalam suatu UU. Kedua, Konstitusi RIS 1949, menegaskan mekanisme pendelegasian kewenangan "termaktub secara atributori" dalam kaidah konstitusi. Hal ini dapat dilihat dalam mekanisme penentuan kewenangan negara bagian lebih awal, kemudian disusul penentuan kewenangan federal. Proses penentuan ini menandai mekanisme pendelegasian kewenangan dari negara bagian ke negara federal. Ketiga, UUDS RI 1950 menegaskan mekanisme pendelegasian kewenangan "termaktub secara atributori" dalam kaidahnya, yaitu: 1) daerah besar dan kecil mempunyai hak otonomi dalam mengurus dan melaksanakan pemerintahan di daerah. 2) pemberian otonomi seluas-luasnya kepada pemerintahan di daerah. 3) pendelegasian kewenangan pangkal melalui UU Pembentukan Daerah Otonom sebagai urusan rumah tangga daerah. 4) pendelegasian kewenangan tambahan tugas (urusan) kepada daerah melalui penerbitan UU penyerahan kewenangan. Keempat, UUD NRI 1945 (Amandemen), menegaskan mekanisme pendelegasian kewenangan "termaktub secara atributori" dalam kaidahnya, yaitu: 1) Pemerintahan daerah (provinsi, kabupaten, kota) diberikan hak otonomi dalam mengatur dan mengurus rumah tangganya. 2) adanya pembagian kekuasaan (kewenangan) antara pemerintah pusat dengan pemerintah daerah, dan antara pemerintah daerah provinsi dengan pemerintah daerah kabupaten dan kota. 3) adanya peraturan perundang-undangan di tingkat daerah dalam melaksanakan pemerintahan di daerah.

Jadi dalam pemberlakuan kelima hukum dasar negara tersebut diatas, memberikan penafsiran terjadinya pergeseran makna mekanisme pendelegasian kewenangan kepada pemerintah daerah yang termaktub secara atributori dalam konstitusi, yaitu: UUD RI 1945 (Proklamasi-Dekrit) tidak tercantum secara eksplisit mekanisme dalam pendelegasian kewenangan. UUDS RI 1950 secara eksplisit mencantumkan adanya mekanisme pendelegasian melalui, yaitu: penetapan dalam kaidah konstitusi, UU Pemerintahan Daerah, UU Pembentukan Daerah, dan PP Pengakuan dan Penyerahan Kewenangan. UUD NRI 1945 (amandemen) secara eksplisit mencantumkan adanya mekanisme pendelegasian melalui, yaitu: penetapan dalam kaidah konstitusi, UU Pemerintahan Daerah, UU Pembentukan Daerah, dan PP Pengakuan dan Penyerahan Kewenangan. Sementara Konstitusi RIS 1949 secara eksplisit mengatur mekanisme pendelegasian dalam kaidahnya. 


\section{Pergeseran Makna Dalam Kaidah UU Pemerintahan Daerah}

\section{Penafsiran Kaidah Bentuk dan Susunan Pemerintahan Daerah}

Kaidah UU RI No. 1 Tahun 1945 dalam Pasal 2 jo Pasal 3 yang memberikan penafsiran atas dua subyek lembaga, yaitu: BPRD (sebagai badan legislatif daerah) dan Badan Eksekutif Daerah, yang keduanya di pimpin oleh Kepala Daerah, atau terdapat tiga subyek organ jabatan, yaitu: 1. BPRD (sebagai badan legislatif daerah). 2. Badan Eksekutif Daerah. 3. Kepala Daerah. Jadi bentuk dan susunan pemerintahan daerah digambarkan: Pemerintah Daerah Propinsi, Karesidenan, Kabupaten dan Kota terdiri atas BPRD (Badan Legislatif Daerah)-(Badan Eksekutif Daerah) yang keduanya dipimpin oleh Kepala Daerah (Ketua BPRD dan Ketua BED).

Sementara kaidah UU RI No. 22 Tahun 1948 dalam Pasal 2 memberikan penafsiran dalam dua subyek lembaga, yaitu: DPRD dan DPD, atau terdapat tiga subyek organ jabatan, yaitu: 1. DPRD (sebagai badan legislatif daerah). 2 . DPD (Badan Eksekutif Daerah). 3. Kepala Daerah. Jadi bentuk dan susunan pemerintahan daerah digambarkan: Pemerintah Daerah Propinsi, Kabupaten (Kota Besar), Desa (Kota Kecil) terdiri dari: DPRD (Badan Legislatif Daerah) - DPD yang dipimpin oleh Kepala Daerah (anggota). Kaidah UU RI No. 1 Tahun 1957 dalam Pasal 5 memberikan penafsiran dalam dua subyek lembaga yaitu: DPRD dan Dewan Pemerintah Daerah, atau terdapat tiga subyek organ jabatan, yaitu: 1. DPRD. 2. DPD. 3. Kepala Daerah. Jadi bentuk dan susunan pemerintahan daerah digambarkan: Pemerintah Dati I (D.I. Tkt I-Kotaraya), Pemerintah Dati II (D.I. Tkt II-Kotapraja), Pemerintah Dati III (D.I. Tkt III) terdiri daripada DPRD (Badan Legislatif Daerah)-DPD yang dipimpin oleh Kepala Daerah (anggota)

Pen-Pres RI No. 6 Tahun 1959 dalam kaidah Pasal 1 jo Pasal 2 memberikan penafsiran dalam dua subyek lembaga, yaitu: Kepala Daerah (dibantu oleh BPH) dan DPRD, atau terdapat dua subyek organ jabatan, yaitu: 1. DPRD. 2. Kepala Daerah. Jadi bentuk dan susunan pemerintahan daerah digambarkan: Pemerintah Dati I (D.I. Tingkat I-Kotaraya), Pemerintah Dati II (D.I. Tingkat II-Kotapraja), Pemerintah Dati III (D.I. Tingkat III) terdiri dari Kepala Daerah (BPH) - DPRD. UU RI No. 18 Tahun 1965, dalam kaidah Pasal 5 jo Pasal 6 memberikan penafsiran dalam dua subyek lembaga, yaitu: Kepala Daerah (dibantu oleh Wakil Kepala Daerah dan BPH), atau terdapat dua subyek organ jabatan, yaitu: 1. DPRD. 2. Kepala Daerah. Jadi bentuk dan susunan pemerintahan daerah digambarkan: Pemerintah 
Propinsi (Kotaraya-Dati I), Pemerintah Kabupaten (Kotamadya-Dati II), Pemerintah Kecamatan (Kotapraja-Dati III) terdiri dari Kepala Daerah (Wakil KD \& BPH) - DPRD.

U RI No. 5 Tahun 1974 dalam kaidah Pasal 13 memberikan penafsiran pemerintah daerah yang dalam pelaksanaannya satu kesatuan antara Kepala Daerah bersama dengan DPRD, atau terdapat dua subyek jabatan, tetapi pada dasarnya hanya satu subyek lembaga/instutisi yang tidak terpisahkan, yaitu: 1 . Kepala Daerah. 2. DPRD. Jadi bentuk dan susunan pemerintahan daerah digambarkan: Pemerintah Dati I/Daerah Propinsi, Pemerintah Dati II/Kabupaten, Pemerintah Dati II/Kotamadya adalah Kepala Daerah (Wakil KD) dan DPRD, serta Pemerintah Kota Administratif adalah Walikotif dan Sekretaris.

UU RI No. 22 Tahun 1999 dalam kaidah Pasal 1 dan Pasal 14 memberikan penafsiran dengan tegas mengenai adanya tiga subyek lembaga, yaitu: 1. Pemerintah Daerah (Kepala Daerah beserta perangkat Daerah Otonom sebagai Badan Eksekutif Daerah). 2. Dewan Perwakilan Rakyat Daerah, (Badan Legislatif Daerah). 3. Pemerintahan Daerah (gabungan antara Pemerintah Daerah dan DPRD), atau terdapat tiga subyek organ jabatan, yaitu: 1. Pemerintah Daerah. 2. DPRD. 3. Pemerintahan Daerah. Jadi berdasarkan penafsiran ini, maka bentuk dan susunan pelaksanaan pemerintahan daerah dapat digambarkan: Pemerintahan Propinsi, Pemerintahan Kabupaten, Pemerintahan Kota terdiri dari DPRD - Pemerintah Daerah (Kepala Daerah/Perangkat Daerah).

UU RI No. 32 Tahun 2004 dalam kaidah Pasal 1, Pasal 2, Pasal 3 memberikan penafsiran dalam tiga subyek lembaga, yaitu: 1. Pemerintah Daerah (Kepala Daerah dan dibantu Perangkat Daerah), 2. Dewan Perwakilan Rakyat Daerah. 3. Pemerintahan Daerah (gabungan antara Pemerintah Daerah dan DPRD), atau subyek organ jabatan, antara lain: 1. Pemerintahan Daerah Propinsi. 2. Gubernur. 3. DPRD Propinsi. 4. Pemerintahan Daerah Kabupaten. 5. Bupati. 6. DPRD Kabupaten. 7. Pemerintahan Daerah Kota. 8. Walikota. 9. DPRD Kota. Jadi berdasarkan penafsiran UU, maka bentuk dan susunan pelaksanaan pemerintahan daerah dapat digambarkan: Pemerintah Propinsi, Pemerintah Kabupaten, Pemerintah Kota terdiri daripada DPRD Pemerintah Daerah (Kepala Daerah/Perangkat Daerah).

Jadi dari penafsiran kaidah yang termaktub dalam pemberlakuan UU Pemerintahan Daerah mengenai bentuk dan susunan (satuan subyek organ/ lembaga/jabatan/institusi) dapat digambarkan pergeseran-pergeseran makna yang terjadi, antara lain: Pertama, UU No. 22/1948 jo UU No. 1/1957 jo 
Penpres No. 6/1959 jo UU No. 18/1965 dari subyek lembaga berdiri sendiri dalam satuan pemerintahan daerah sama, yaitu masing-masing mencantumkan kata "terdiri daripada" yang memberikan makna bahwa bentuk susunan pemerintahan di daerah dilaksanakan oleh lembaga lebih dari satu yang berbeda atau lebih dari 1 subyek lembaga yang berdiri sendiri dan sejajar (mitra): Namun dalam sisi subyek organ/jabatan berbeda, seperti UU No. 22/1948 jo UU No. 1/1957 terdiri DPRD dan DPD (dipimpin oleh KD) tetapi kedudukan Kepala Daerah dalam kedua UU sebagai Ketua DPD berbeda. Kedudukan KD dalam UU No. 22/1948 hanya sebagai alat pemerintah pusat untuk mengawasi pekerjaan pemerintah daerah, sedangkan dalam UU No. 1/1957 kedudukan KD hanya sebagai alat daerah semata-mata. Sementara Penpres No. 6/1959 jo UU No. 18/1965 terdiri KD (Wakil KDH-BPH) dan DPRD, tetapi dalam Penpres No. 6/1959 tidak eksplisit disebutkan mengenai keberadaan Wakil Kepala daerah. Kedua aturan mengamanatkan kedudukan Kepala Daerah sebagai alat pusat dan alat daerah, tetapi Penpres tidak menegaskan bahwa DPRD harus bertanggungjawab kepada Kepala Daerah, sedangkan UU No. 18/1965 dalam penjelasan Pasal 5 ditegaskan bahwa DPRD harus mempertanggungjawabkan pekerjaannya kepada Kepala Daerah sebagai wakil (alat pemerintah pusat) di daerah.

Kedua, UU No. $1 / 1945$ jo UU No. 5/1974 dalam maknanya sebenarnya sama, bahwa dari makna "adalah" dan "bersama dan dipimpin" menunjukkan bahwa dari dua subyek ini sebenarnya adalah satu kesatuan yang tidak terpisahkan. Seperti dalam UU No. 1/1945 dari kaidah "bersama-sama dan dipimpin" memberikan makna bahwa BPRD subyek berada dibawah kekuasaan Kepala Daerah yang juga Ketua Badan Eksekutif Daerah atau subyek lembaga/institusi BPRD dan BED di bawah kekuasaan Kepala Daerah sebagai salah satu subyek jabatan/organ dalam pelaksanaan pemerintahan di daerah (alat pusat dan alat daerah). Sementara dalam UU No. 5/1974 dari kaidah "adalah" memberikan makna bahwa subyek lembaga/institusi/jabatan DPRD dan Kepala Daerah merupakan satu kesatuan dalam susunan pemerintah daerah atau subyek satuan lembaga/jabatan DPRD dan Kepala Daerah merupakan satu dalam satuan pemerintahan daerah.

Ketiga, UU No. 22/1999 jo UU No. 32/2004 menegaskan kaidah yang sama dalam subyek lembaga/institusi/jabatan dalam pelaksanaan pemerintahan daerah, yaitu "DPRD dan Pemerintah Daerah (Kepala Daerah dan Perangkat Daerah) serta kalau ditelaah lebih dalam maka ada subyek "pemerintahan daerah" yang merupakan gabungan subyek antara pemerintah daerah dengan DPRD. UU No. 22/1999 tidak mengatur secara rinci susunan pemerintahan 
daerah dalam tingkatan-tingkatan sedangkan UU No. 32/2004 mengatur secara rinci susunan pemerintahan: pemerintahan Daerah Propinsi, Daerah Kabupaten, Daerah Kota. Namun kalau ditelaah lebih jauh lagi maka ditemukan pergeseran makna dalam pengisian jabatan dan pertanggung jawaban Kepala Daerah, yaitu: dalam kaidah UU No. 22/1999 bahwa Kepala Daerah dalam menjalankan tugas dan kewenangannya bertanggungjawab kepada DPRD serta dipilih dan dapat dijatuhkan oleh DPRD. Sementara dalam kaidah UU No. 32/2004 Kepala daerah memberikan pertanggungjawaban kepada pemerintah serta keterangan pertanggungjawaban kepada DPRD serta dipilih secara lansung oleh rakyat di daerah.

\section{Penafsiran Kaidah Struktur, Tingkatan, Jenis dan Sifat Daerah}

Kaidah UU No. 1/1945 dalam struktur dan tingkatan: 1 . Propinsi/Karesidenan. 2. Kota Berautonomi dan Kabupaten. Serta jenis dan Sifat daerah terdiri: Daerah ada KNID (berautonomi), Daerah tidak ada KNID (tidak berautonomi-administratif). ${ }^{35}$ Kaidah UU No. 5/1974 memberikan penafsiran: (1) struktur dan tingkatan, yaitu: daerah tingkat I dan daerah tingkat II. (2) Pelaksanaan asas dekonsentrasi diwujudkan dalam struktur dan tingkatan, yaitu: wilayah propinsi dan ibukota negara, Kabupaten, Kotamadya, Kecamatan, Kota Administratif. Serta jenis dan Sifat daerah terdiri: Daerah otonom (desentralisasi), Daerah administratif (dekonsentrasi), Daerah Istimewa. $^{36}$ Kaidah UU No. 22/1999 memberikan penafsiran mengenai

35 UU RI No. 1 Tahun 1945 Provinsi, Kewedanan dan Kecamatan adalah satuan pemerintahan tingkat daerah yang tidak disertai KNID. Pemerintahan daerah yang memiliki KNID adalah yang berhak mengatur rumah tangganya sendiri, yakni : Karesidenan, Kota, Kabupaten, sedangkan pemerintahan yang tidak memiliki KNID, seperti: Propinsi, Kewedanan dan Kecamatan sepenuhnya diperlakukan sebagai daerah (wilayah) administratif.

${ }^{36}$ UU RI No. 5 Tahun 1974 menegaskan dalam Pasal 2 "... wilayah NKRI dibagi dalam daerah-daerah otonom dan wilayah administratif". Pasal 3 "...pelaksanaan azas desentralisasi dibentuk dan disusun Daerah Tingkat I dan Daerah Tingkat II". Pasal 73 "....pelaksanaan azas dekonsentrasi, wilayah Negara Kesatuan Republik Indonesia dibagi dalam Wilayah-wilayah Propinsi dan Ibu kota Negara. Ayat (2) Wilayah Propinsi dibagi dalam Wilayah Kabupaten dan Kota madya. Ayat (3) Wilayah Kabupaten dan Kotamadya dibagi dalam Wilayah-wilayah Kecamatan. Ayat (4) Apabila dipandang perlu sesuai dengan pertumbuhan dan perkembangannya, dalam Wilayah Kabupaten dapat dibentuk Kota Administratip yang pengaturannya ditetapkan dengan Peraturan Pemerintah". 
struktur dan tingkatan: 1. Daerah Propinsi. 2. Daerah Kabupaten dan Daerah Kota. Jenis dan Sifat daerah terdiri: Daerah Otonom (desentralisasi), Daerah Istimewa, Wilayah Administrasi. ${ }^{37}$ Kaidah UU No. 32/2004 dalam struktur dan tingkatan daerah terdiri atas: 1. Daerah Propinsi. 2. Daerah Kabupaten dan Daerah Kota. Serta jenis dan Sifat daerah terdiri: Daerah otonom, Daerah Istimewa, Daerah Khusus. ${ }^{38}$

Jadi kaidah yang termaktub dalam UU No. $1 / 1945$ jo UU No. 5/1974 jo UU No. 22/1999 jo UU No. 32/2004 membagi struktur dan tingkatan daerah dalam "dua tingkatan" tetapi dalam penamaan berbeda, yaitu: Pertama, daerah yang diklasifikan dalam tingkatan dan penamaan "Propinsi, Karesidenan, Daerah Tingkat I". Kedua, daerah yang diklasifikan dalam tingkatan dan penamaan "Kabupaten, Kota, Kotamadya, Daerah Tingkat II. Ketiga, daerah yang diklasifikasi dalam jenis, sifat dan istilah "Daerah Otonom, Daerah (wilayah) Administratif, Daerah berautonomi dan tidak berautonomi, Daerah Istimewa, Daerah Khusus. Kesimpulan di atas dari keempat UU organik memberikan tingkatan yang sama, tetapi dalam penerapannya memberikan penafsiran yang berbeda, antara lain: Pertama, Daerah Propinsi (Dati I) dalam UU No. 1/1945 diposisikan sebagai daerah administratif (tidak berautonomi) yang tidak mempunyai KNID, sementara dalam UU No. 5/1974 "propinsi" sebagai pelaksanaan asas dekonsentrasi dan "Dati I" sebagai pelaksanaan asas desentralisasi, sedangkan dalam UU. No. 22/1999 jo UU No. 32/2004 "propinsi" sebagai daerah otonom tetapi dilekati sebagai "wilayah administratif" atau wakil pemerintah pusat dalam pelaksanaan pemerintahan di daerah. Kedua, "Daerah Propinsi" dalam kaidah UU No. 1 Tahun 1945 jo UU No. 5/1974 kedudukannya "hierarkhies atau

${ }^{37}$ UU RI No. 22 Tahun 1999 menegaskan dalam Pasal 2 "ayat (1) Wilayah Negara Kesatuan Republik Indonesia dibagi dalam Daerah Propinsi, Daerah Kabupaten, dan Daerah Kota yang bersifat otonom, ayat (2) Daerah Propinsi berkedudukan juga sebagai Wilayah Administrasi”.

${ }^{38}$ UU RI No. 32 Tahun 2004. UU ini menegaskan dalam Pasal 2 menegaskan "ayat (1) Negara Kesatuan Republik Indonesia dibagi atas daerah-daerah provinsi dan daerah provinsi itu dibagi atas kabupaten dan kota. Ayat (2) Pemerintahan daerah sebagaimana dimaksud pada ayat (1) mengatur dan mengurus sendiri urusan pemerintahan menurut asas otonomi dan tugas pembantuan. Ayat (8) Negara mengakui dan menghormati satuan-satuan pemerintahan daerah yang bersifat khusus atau bersifat istimewa yang diatur dengan undang-undang. Ayat (9) Negara mengakui dan menghormati kesatuan masyarakat hukum adat beserta hak tradisionalnya sepanjang masih hidup dan sesuai dengan perkembangan masyarakat dan prinsip NKRI'. 
daerah atasan" dari daerah di bawahnya, sementara dalam kadiah UU No. 22/1999 jo UU No. 32/2004 kedudukannya "tidak hierarkhies atau bukan daerah atasan" dari daerah di bawahnya.

Analisis lainnya dalam UU No. $22 / 1948$ jo UU No. $1 / 1957$ jo UU No. 18/1965 membagi struktur dan tingkatan daerah dalam "tiga tingkatan" tetapi dalam penamaan berbeda, seperti UU No. 22/1948 dalam kaidah pasal 1 dan penjelasan, ditafsirkan bahwa daerah terbagi atas, yaitu: 1. Propinsi. 2. Kabupaten (Kota Besar). 3. Desa (Kota Kecil). Serta jenis dan Sifat daerah terdiri: Daerah Otonom dan Daerah Istimewa. ${ }^{39}$ Sementa UU No. 1/1957 dalam kaidah Pasal 2 dapat ditafsirkan bahwa struktur dan tingkatan daerah terdiri dari, yaitu: (1) daerah besar dan kecil dalam 3 (tiga) tingkat: Dati ke I, (Kotaraya Jakarta Raya), Dati ke II (Kotapraja), dan Dati ke III. (2) Daerah Swapraja bisa dalam wujud Daerah Istimewa tingkat ke I,II atau III atau Daerah Swatantra tingkat ke I, II atau III. (3) Daerah Istimewa bisa dalam wujud Dati ke I,II atau III . Serta jenis, Sifat dan istilah daerah terdiri : Daerah Swatantra, Daerah Istimewa, Daerah Swapraja, Daerah Kotaraya dan Kotapraja. ${ }^{40}$ Sedangkan UU No. 18/1965 dalam kaidah Pasal 2, 3 dan 4 UU ini memberikan penafsiran dalam struktur dan tingkatan daerah dalam klasifikasi tiga tingkatan sebagai berikut: (1) Propinsi/Kotaraya sebagai Dati I. (2) Kabupaten/Kotamadya sebagai Dati II. (3) Kecamatan/Kotapraja sebagai Dati III. Serta jenis dan Sifat daerah terdiri: Daerah otonom, Daerah Istimewa. ${ }^{41}$

${ }^{39}$ UU RI No. 22 Tahun 1948 menegaskan dalam Pasal 1 "Daerah Negara RI tersusun dalam tiga tingkatan, ialah: Propinsi, Kabupaten (Kota Besar) dan Desa (Kota Kecil) serta daerah yang bersifat istimewa yang setingkat dengan Propinsi, Kabupaten atau Desa.

${ }^{40}$ UU RI No 1 Tahun 1957 memberikan batasan secara tegas mengenai Daerah Otonom, Daerah Swatantra dan Daerah Istimewa, yang diwujudkan dalam tingkatan daerah, yaitu: a. Daerah tingkat ke I (termasuk Daerah Istimewa tingkat I). b. Daerah tingkat ke II (termasuk Daerah Istimewa tingkat II). c. Daerah tingkat ke III (termasuk Daerah Istimewa tingkat III). Sementara dalam Pasal 2 menegaskan “(1) Daerah besar dan kecil dalam 3 (tiga) tingkat yang derajatnya dari atas ke bawah adalah sebagai berikut: a. Daerah tingkat ke I, termasuk Kotapraja Jakarta Raya, b. Daerah tingkat ke II, termasuk Kotapraja, dan c. Daerah tingkat ke III.

${ }^{41}$ UU RI No. 18 Tahun 1965 menegaskan dalam Pasal 1 "daerah besar dan daerah kecil dalam jenis daerah "Propinsi", "Kabupaten" dan "Kecamatan" sebagaimana halnya dengan istilahistilah "Kotaraya", "Kotamadya", dan "Kotapraja". Sementara dalam Pasal 2 menegaskan "Wilayah Negara RI terbagi habis dalam tiga tingkatan sebagai berikut : a.Propinsi dan/atau kotaraya sebagai daerah tingkat I. B. Kabupaten dan/atau Kotamadya sebagai daerah tingkat II. C. Kecamatan dan/atau Kotapraja sebagai daerah tingkat III". 
daerah atasan" dari daerah di bawahnya, sementara dalam kadiah UU No. 22/1999 jo UU No. 32/2004 kedudukannya "tidak hierarkhies atau bukan daerah atasan" dari daerah di bawahnya.

Analisis lainnya dalam UU No. $22 / 1948$ jo UU No. $1 / 1957$ jo UU No. 18/1965 membagi struktur dan tingkatan daerah dalam "tiga tingkatan" tetapi dalam penamaan berbeda, seperti UU No. 22/1948 dalam kaidah pasal 1 dan penjelasan, ditafsirkan bahwa daerah terbagi atas, yaitu: 1. Propinsi. 2. Kabupaten (Kota Besar). 3. Desa (Kota Kecil). Serta jenis dan Sifat daerah terdiri: Daerah Otonom dan Daerah Istimewa. ${ }^{39}$ Sementa UU No. 1/1957 dalam kaidah Pasal 2 dapat ditafsirkan bahwa struktur dan tingkatan daerah terdiri dari, yaitu: (1) daerah besar dan kecil dalam 3 (tiga) tingkat: Dati ke I, (Kotaraya Jakarta Raya), Dati ke II (Kotapraja), dan Dati ke III. (2) Daerah Swapraja bisa dalam wujud Daerah Istimewa tingkat ke I,II atau III atau Daerah Swatantra tingkat ke I, II atau III. (3) Daerah Istimewa bisa dalam wujud Dati ke I,II atau III . Serta jenis, Sifat dan istilah daerah terdiri : Daerah Swatantra, Daerah Istimewa, Daerah Swapraja, Daerah Kotaraya dan Kotapraja. ${ }^{40}$ Sedangkan UU No. 18/1965 dalam kaidah Pasal 2, 3 dan 4 UU ini memberikan penafsiran dalam struktur dan tingkatan daerah dalam klasifikasi tiga tingkatan sebagai berikut: (1) Propinsi/Kotaraya sebagai Dati I. (2) Kabupaten/Kotamadya sebagai Dati II. (3) Kecamatan/Kotapraja sebagai Dati III. Serta jenis dan Sifat daerah terdiri: Daerah otonom, Daerah Istimewa. ${ }^{41}$

${ }^{39}$ UU RI No. 22 Tahun 1948 menegaskan dalam Pasal 1 "Daerah Negara RI tersusun dalam tiga tingkatan, ialah: Propinsi, Kabupaten (Kota Besar) dan Desa (Kota Kecil) serta daerah yang bersifat istimewa yang setingkat dengan Propinsi, Kabupaten atau Desa.

${ }^{40}$ UU RI No 1 Tahun 1957 memberikan batasan secara tegas mengenai Daerah Otonom, Daerah Swatantra dan Daerah Istimewa, yang diwujudkan dalam tingkatan daerah, yaitu: a. Daerah tingkat ke I (termasuk Daerah Istimewa tingkat I). b. Daerah tingkat ke II (termasuk Daerah Istimewa tingkat II). c. Daerah tingkat ke III (termasuk Daerah Istimewa tingkat III). Sementara dalam Pasal 2 menegaskan “(1) Daerah besar dan kecil dalam 3 (tiga) tingkat yang derajatnya dari atas ke bawah adalah sebagai berikut: a. Daerah tingkat ke I, termasuk Kotapraja Jakarta Raya, b. Daerah tingkat ke II, termasuk Kotapraja, dan c. Daerah tingkat ke III.

${ }^{41}$ UU RI No. 18 Tahun 1965 menegaskan dalam Pasal 1 "daerah besar dan daerah kecil dalam jenis daerah "Propinsi", "Kabupaten" dan "Kecamatan" sebagaimana halnya dengan istilahistilah "Kotaraya", "Kotamadya", dan "Kotapraja". Sementara dalam Pasal 2 menegaskan "Wilayah Negara RI terbagi habis dalam tiga tingkatan sebagai berikut : a.Propinsi dan/atau kotaraya sebagai daerah tingkat I. B. Kabupaten dan/atau Kotamadya sebagai daerah tingkat II. C. Kecamatan dan/atau Kotapraja sebagai daerah tingkat III". 
sedangkan Penpres No. 6/1959 tidak mencantumkan dalam kaidahnya. Ketiga, kaidah UUDS RI 1950 dalam Pasal 131, 132, 133, yang dijabarkan lebih lanjut melalui UU No. 1/1957 dalam kaidahnya memperluas penafsiran kaidah UUD) dalam tiga tingkatan. Keempat, kaidah Konstitusi RIS 1949 (Dekrit) dalam kaidahnya dijabarkan lebih lanjut melalui UU No. 22/1948 dan UU NIT 1950. Dari kedua UU organik sebagai peraturan pelaksanaan (penjabaran) dari kaidah Konstitusi, dalam kaidahnya menafsirkan berbeda, karena pengaturan lebih lanjut mengenai struktur pemerintahan daerah dalam wilayah masing-masing, diserahkan kepada kewenangan negara bagian dan satuan kenegaraan yang berdiri sendiri.

\section{Penafsiran Kaidah Prosedur dan Mekanisme Pendelegasian Kewenangan}

Pemberlakuan UU RI No. 1 Tahun 1945 tidak menegaskan secara tegas antara wewenang sebagai daerah otonom dan wewenang sebagai penyelenggara fungsi dekonsentrasi, serta pelaksanaan tugas-tugas medebewind. Namun, kalau dicermati dalam penjelasan, maka dapat ditemukan mekanisme pendelegasian kewenangan dalam kaidah, antara lain: (1) adanya amanat kepada BPRD dan Kepala Daerah untuk menjalankan pemerintahan di daerah sebagai urusan rumah tangga daerah: (2) Kewenangan dalam membuat peraturan daerah dalam rangka desentralisasi; serta (3) Kewenangan yang bersifat delegatif dalam hal dekonsentrasi dan tugas pembantuan untuk menjalankan sesuatu hal yang ditetapkan oleh pemerintah pusat.

Sementara dalam pemberlakuan UU RI No. 22 Tahun 1948, pendelegasian kewenangan dilaksanakan melalui: Pertama, mekanisme delegasi UU Pembentukan Daerah. Ini dapat dilihat dalam kaidah bahwa kewenangan daerah harus disebutkan dalam setiap UU pembentukan daerah, yang kewenangannya bisa seluruhnya otonomi atau sepenuhnya medebewind, dan sebagian otonomi atau sebagian medebewind yang dijelaskan pada pembentukan pemerintahan daerah yang berhak mengatur dan mengurus rumah tangganya sendiri dalam proses mekanisme desentralisasi (penyerahan). Kedua, mekanisme sub-delegasi PP dan PERDA. Ini dapat dilihat dalam kaidah, bahwa kewenangan yang didelegasikan kepada pemerintah daerah dapat diserahkan kepada pemerintah daerah di bawahnya melalui pengaturan dalam PERDA. Namun, dengan sendirinya kewenangan yang telah didelegasikan dapat dicabut dan dialihkan oleh pemerintah pusat dengan PP, begitupun kewenangan yang dilimpahkan kepada pemerintah daerah di 
bawahnya dapat dialihkan dengan PERDA kepada badan yang harus menjalankan pekerjaan itu. Menurut UU ini, penyerahannya dapat dalam dua bentuk, (1) penyerahan penuh (hak otonom). (2) penyerahan tidak penuh (hak medebewind).

Saat Pemberlakuan UU RI No. 1 Tahun 1957 pendelegasian kewenangan dilaksanakan melalui: Pertama, mekanisme pendelegasian bersamaan dengan penerbitan dan pemberlakuan UU ini, serta pendelegasian bisa juga melalui UU Pembentukan Daerah. Mekanisme pendelegasian kewenangan ke daerah ditetapkan dalam "UU Pembentukan Daerah". Urusan tugas pembantuan dalam menjalankan peraturan perundang-undangan dapat diserahkan atau dilimpahkan kepada pemerintah daerah melalui penetapan dalam UU pembentukan dan peraturan lainnya. Jadi mekanisme pendelegasian kewenangan melalui media desentralisasi yang ditegaskan dalam UU Pembentukan Daerah sebagai kewenangan awal (pangkal). Kedua, mekanisme sub-delegasi PP dan PERDA. Ini terlihat dalam kaidah bahwa kewenangan dan/atau urusan bisa ditambah dengan "PP" atas usul DPRD, serta dapat menyerahkan atau mengalihkan urusan tersebut dengan penetapan "Perda" kepada daerah tingkat bawahannya. Demikian juga melalui Perda, dapat ditugaskan kepada pemerintah daerah dari tingkat bawahan untuk memberikan pembantuan menjalankan peraturan daerah. Di sisi lain, masih diperkenalkan pendelegasian kewenagan melalui peraturan pelaksanaan UU ini, seperti dengan penerbitan beberapa PP dan Keppres, serta melalui penetapan dalam Perda kalau berkenan dengan pendelegasian kewenangan kepada daerah bawahan. Sedangkan melalui media medebewind dalam wujud meminta bantuan kepada daerah untuk menjalankan peraturan perundangan atau pengesahan sesuatu urusan dalam hak medebewind. Jadi, medebewind dapat dilakukan dengan UU pembentukan daerah atau melalui penetapan dalam PP, baik dari pemerintah pusat kepada daerah (hak medebewind yang diserahkan kepada daerah dari pemerintah pusat tidak dapat lagi diserahkan kepada daerah di bawahnya), maupun dari daerah kepada daerah di bawahnya (hanya khusus mengenai hal yang terletak dalam dataran otonomi daerah). Jadi kalau penyerahan hak medebewind melalui PP dan Perda, maka yang diserahi tugas untuk menjalankannya adalah DPD.

Sementara dalam pemberlakuan Pen-Pres RI No. 6 Tahun 1959 mekanisme pendelegasian kewenangan dalam politik desentralisasi dan dekonsentrasi tidak secara tersurat ditegaskan karena hanya dengan batasan bahwa pemberian hak kepada daerah untuk mengatur dan mengurus rumah tangga sendiri. Sedangkan dalam Pemberlakuan UU RI No. 18 Tahun 1965, 
menegaskan bahwa mekanisme pendelegasian kewenangan dalam UU ini adalah: Pertama, mekanisme pendelegasian kewenangan diawali pada saat terbitnya UU pembentukan daerah sebagai urusan pangkal yang disertai alat perlengkapan dan pembiayaannya. Kedua, kewenangan daerah dapat ditambah setiap waktu melalui penetapan dalam "PP" atas usul dari DPRD bagi Dati I dan usul kepala daerah bagi Dati II dan III. Ketiga, kewenangan daerah dapat dialihkan kepada daerah bawahan melalui "PERDA", yang di syahkan oleh Mendagri bagi Dati I dan kepala daerah bagi Dati II dan III. Pemberlakuan UU RI No. 5 Tahun 1974 menegaskan, bahwa mekanisme pendelegasian yang ditegaskan dalam UU ini adalah: Pertama, bahwa pendelegasian kewenangan dilakukan dalam UU pembentukan daerah. Kedua, dan penambahan kewenangan dilakukan dengan peraturan pemerintah dalam konteks desentralisasi dan tugas pembantuan dari pusat ke daerah melalui PP. Ketiga, melalui PERDA Dati I dapat menugaskan kepada Dati II.

Pemberlakuan UU RI No. 22 Tahun 1999, menekankan bahwa mekanisme pendelegasian melalui, yaitu: Pertama, pendelegasian kewenangan dilakukan dan diatur bersamaan dalam penerapan aturan, di mana pendelegasian kewenangan secara pasif dilakukan melalui peraturan organik. Kedua, pendelegasian kewenangan dilakukan secara aktif melalui penerbitan peraturan pemerintah dan Keppres yang berisikan pelimpahan kewenangan Presiden kepada Mendagri untuk melakukan pengakuan kewenangan pemerintah daerah serta koordinasi lembaga pemerintahan lainnya. Ketiga, pendelegasian kewenangan dilakukan melalui kewenangan awal (pangkal) ditetapkan dengan UU Pembentukan Daerah. Keempat, pendelegasian kewenangan dilakukan melalui pengaturan mengenai penyerahan dan pelimpahan kewenangan diatur dalam PP. Kelima, pendelegasian kewenangan dilakukan melalui, pengaturan kewenangan provinsi dan kabupaten dan kota diatur dalam PP.

Pemberlakuan UU RI No. 32 Tahun 2004, menekankan bahwa mekanisme pendelegasian melalui, yaitu: Pertama, bahwa pendelegasian kewenangan dilakukan dan diatur secara tersurat bersamaan dalam penerapan aturan, di mana pendelegasian kewenangan secara "pasif" dilakukan melalui UU ini. Kedua, bahwa pendelegasian kewenangan dilakukan secara "aktif" melalui penerbitan "PP" dan "Keppres" yang berisikan pelimpahan kewenangan Presiden kepada Mendagri untuk melakukan pengakuan kewenangan pemerintah daerah serta koordinasi lembaga pemerintahan lainnya. Ketiga, bahwa pendelegasian kewenangan dilakukan melalui kewenangan awal (pangkal) ditetapkan dengan UU Pembentukan Daerah, di 
mana kewenangan tersebut menjalankan otonomi seluas-luasnya untuk mengatur dan mengurus sendiri urusan pemerintahan berdasarkan asas otonomi dan tugas pembantuan. Keempat, bahwa pendelegasian kewenangan dilakukan melalui pengaturan mengenai penyerahan dan pelimpahan kewenangan diatur dalam "PP". Kelima, bahwa pendelegasian kewenangan dilakukan melalui, pengaturan kewenangan provinsi dan kewenangan kabupaten dan kota diatur dalam "PP". Kewenangan yang diserahkan dapat melimpahkan sebagian urusan pemerintahan kepada perangkat atau wakil di daerah atau dapat menugaskan kepada daerah dan/atau pemerintahan desa.

Jadi dari penafsiran kaidah masing-masing UU organik, khususnya mengenai mekanisme pendelegasian kewenangan, maka dapat dipaparkan pergeseran makna yang terjadi dalam beberapa hal, antara lain: Pertama, ada UU organik yang menegaskan mekanisme pendelegasian bersamaan dengan terbitnya atau berlakunya UU organik, seperti: UU No. 1/1957, UU No. $22 / 1999$, UU No. 32/2004. Hal ini memberikan indikasi bahwa pendelegasian kewenangan kepada pemerintahan daerah melalui mekanisme "Atribusi UUD" dan "delegasi UU", serta metode dalam penentuan kewenangan pemerintah daerah memakai pola ultra vires yaitu tugas dan kewenangan ditegaskan secara rinci dalam kaidah UU. Kedua, ada UU organik yang menegaskan bahwa mekanisme pendelegasian diawali dengan "delegasi" UU Pembentukan Daerah kemudian PP Penyerahan dan dilanjutkan "sub-delegasi" PERDA pengalihan kepada daerah bawahan, seperti: UU No. 22/48, UU No. 18/1965, UU No. $5 / 1974$. Hal ini memberikan indikasi pendelegasian kewenangan dengan mekanisme "delegasi" melalui UU dan PP serta "sub-delegasi" melalui PERDA. Sementara metode dalam penentuan kewenangan memakai pola general competence yaitu penentuan kewenangan secara umum dalam UU pemerintahan daerah dan kemudian dipergunakan ultra vires yaitu penentuan secara rinci kewenangan dalam UU pembentukan daerah dan PP penyerahan. Ketiga, ada UU organik yang menegaskan secara tersirat (samar-abstrak) mengenai mekanisme pendelegasian kewenangan, seperti: UU No. 1/1945. Keempat, ada UU organik yang tidak mengatur sama sekali mekanisme pendelegasian, seperti: Penpres No. 6/1959 dan UU NIT No. 44/1950. Kelima, ada UU organik yang memperbolehkan (memperkenankan) terjadi "subdelegasi" atau kewenangan yang didelegasikan dapat di delegasikan lagi kepada pemerintah daerah (pejabat) di bawahnya, seperti: UU No. 32/2004 tetapi terbatas pada perangkat daerah atau pemerintah desa. UU No. 5/1974 melalui PERDA Tk.I dapat menugaskan kepada Dati II. UU No. 18/1965 melalui PERDA kepada daerah bawahan setelah mendapat pengesahan dari 
pejabat atasan. UU No. 1/1957 melalui PERDA dapat mengalihkan kepada daerah bawahan. UU No. 22/1948 melalup PERDA dapat dialihkan kepada daerah bawahan serta melalui PERDA lagi kewenangan tersebut dapat dialihkan lagi kepada suatu badan (pejabat) dibawahnya. Keenam, ada UU organik yang memperbolehkan (memperkenankan) terjadi "sub-delegasi" atau kewenangan yang didelegasikan kepada pemerintah daerah dapat di delegasikan lagi kepada pemerintah daerah (pejabat) di bawahnya, seperti : UU No. 22/1999.

Sementara kalau kajian bagian ini dikaitkan dengan kaidah yang termaktub dalam hukum dasar negara, maka akan tampak pergeseran dalam penafsiran maknanya, antara lain: Pertama, kaidah UUD RI 1945 (Proklamasi) dalam Pasal 18 dan penjelasannya, yang dijabarkan lebih lanjut melalui UU No. 1 Tahun 1945 dan UU No. 22 Tahun 1948. Dari kedua UU organik sebagai peraturan pelaksanaan (penjabaran) dari kaidah UUD RI 1945, dalam kaidah menafsirkan berbeda, yaitu : UU No. 1/1945 tidak menegaskan secara tersurat "sama" dengan kaidah UUD, sementara UU No. 22/1948 "memperluas" penafsiran kaidah UUD dengan menegaskan bahwa mekanisme pendelegasian dapat melalui UU pembentukan daerah dan PP penyerahan/pengakuan. Kedua, kaidah UUD RI 1945 (Dekrit) dalam Pasal 18 dan penjelasannya, yang dijabarkan lebih lanjut melalui UU No. 1/1957, Penpres No. 6/1959, UU No. 18/1965, UU No.5/1974, UU No. 22/1999. Dari UU organik sebagai peraturan pelaksanaan (penjabaran) dari kaidah UUD RI 1945, dalam kaidahnya menafsirkan berbeda, yaitu: dalam dua tingkatan (tidak memperluas penafsiran kaidah UUD) sementara UU No. 1/1957 dan UU No. 22/1999 menegaskan mekanisme pendelegasian melalui pemberlakuan UU secara positif, UU No. 18/1965 dan UU No. 5/1974 "memperluas" penafsiran kaidah UUD dengan menegaskan bahwa mekanisme pendelegasian dapat melalui UU pembentukan daerah dan PP penyerahan/pengakuan, sedangkan Penpres No. 6/1959 tidak menegaskan secara tersurat "sama" dengan kaidah UUD. Ketiga, kaidah UUDS RI 1950 dalam Pasal 131,132,133, yang dijabarkan lebih lanjut melalui UU No. 1/1957 dalam kaidahnya "memperluas" penafsiran kaidah UUD. Keempat, kaidah Konstitusi RIS 1949 (Dekrit) dalam kaidahnya dijabarkan lebih lanjut melalui UU No. 22/1948 dan UU NIT 1950. Dari kedua UU organik sebagai peraturan pelaksanaan (penjabaran) dari kaidah Konstitusi, dalam kaidahnya menafsirkan berbeda, karena pengaturan lebih lanjut mengenai struktur pemerintahan daerah dalam wilayah masing-masing, diserahkan kepada kewenangan negara bagian dan satuan kenegaraan yang berdiri sendiri. 


\section{Penutup}

Pelaksanaan pemerintahan (di) daerah memiliki justifikasi filosofis dari hukum dasar negara, cita pendirian negara, dan hakekat pemerintahan di negara kesatuan. Aspek filosopis tercermin dalam kaidah pasal-pasal dalam batang tubuh yang lahir dari perdebatan yang alot dan menghasilkan kesepakatan mengenai hal yang harus diatur dalam hukum dasar negara, perspektif pendirian negara, pelaksanaan sistem pemerintahan, dan dasar penyelenggaraan pemerintahan pada negara kesatuan. Dari proses perdebatan pada perumusan dan penyusunan naskah hukum dasar negara, dapatlah dipahami kesepakatan yang dilahirkan dari berbagai visi, aliran, konsep pemikiran kenegaraan, serta harapan para pendiri negara untuk mendirikan negara diatas segala golongan, kelompok, agama, dan aliran.

Berdasarkan kajian kaidah hukum dasar negara dan kaidah peraturan perundang-undangan serta dinamika dalam proses penyusunan dan perumusannya, maka pelaksanaan pemerintahan di daerah memiliki landasan secara filosofis dalam pemberlakuan dan realita dalam pelaksanaannya, yaitu: pendelegasian kewenangan dalam pelaksanaan pemerintahan di daerah, adalah adanya keseimbangan antara penguatan (pemberdayaan) pemerintahan daerah dengan menjaga keutuhan dan kelansungan "Negara Kesatuan Republik Indonesia". Keseimbangan menjadi sarana dalam mewujudkan harapan dan cita-cita para pendiri negara yaitu: "pemerintahan yang berdasar atas hukum yang dijiwai paham demokrasi dengan penguatan sendi desentralisasi pelaksanaan pemerintahan di daerah". Jadi penjabaran kaidah hukum dasar negara yang dilakukan dalam peraturan pelaksanaan, turut dipengaruhi oleh situasi dan kondisi dinamika ketatanegaraan pada saat-saat tertentu, visi dan misi pemegang tampuk pemerintahan pada saat ini. 


\section{Daftar Pustaka}

Asshiddiqie, Jimly. Gagasan Kedaulatan Rakyat dalam Konstitusi dan Pelaksanaannya di Indonesia, Jakarta: Ichtiar Baru Van Hoeve, 1994.

Banovets, James M. Managing Local Government, Cases in Decision Making, Municipal Management, International City Management Association, $2^{\text {nd }}$, Washintong: Printed, 1994.

Budiardjo, Miriam. Dasar-Dasar Ilmu Politik, Jakarta, Gramedia, 1980.

Finkelstein, Lawrence S. The Indonesiaan Federal Problem, Pacific Affair, $\mathrm{XXI} / 3$, September 1951.

Gadjong, Agussalim Andi. Pemerintahan Daerah, Kajian Politik dan Hukum, Jakarta, Ghalia Indonesia, 2007.

Hatta, Mohammad. Demokrasi Asli Indonesia dan Kedaulatan Rakyat (1932), Jakarta: Bulan Bintang, 1976. . Kedaulatan Rakyat, Surabaya: Usaha Nasional, 1967.

Kelsen, Hans. General Theory of Law and State, New York, Russell \& Russell, 1974.

Kusuma, RM. A. B. Lahirnya Undang-Undang Dasar 1945, Jakarta, Pusat Studi HTN FH-UI, 2004.

Marzuki, Laica. Berjalan-Jalan di Ranah Hukum, Buku Kesatu, Jakarta, Sekjen \& Kepaniteraan MK-RI, 2006.

Nasution, A. H. Sekitar Perang Kemerdekaan Indonesia I, Bandung: Angkasa, 1977.

Smith, B.C., Decentralization: The Territorial Dimension of The State, London: Asia Publishing House, 1985.

Strong, C. F. Modern Political Constitution, London: Sidswick \& Jaclison Limited, 1960.

Tresna, R. Bertamasya Ke-Taman Ketatanegaraan, Bandung: Dibya, tanpa tahun.

Wheare, K. C. Modern Constitutions, London: Oxford University Press, 1966.

Yamin, M. Naskah Persiapan UUD 1945, Jakarta: Prapanca, 1959. 